\title{
Auditor Choice in Italian Non-Listed Firms
}

\author{
GAETANO MATONTI*, JON TUCKER** and AURELIO TOMMASETTI* \\ * University of Salerno, Italy, ** University of the West of England, UK
}

\begin{abstract}
Purpose: This paper investigates auditor choice in those Italian non-listed firms adopting the 'traditional' model of corporate governance. In Italy, non-listed firms can choose between two types of auditor: the Board of Statutory Auditors (BSA), that is, the statutory auditors, or an 'external' auditor. At the same time, a BSA conducts the administrative auditing for all companies with equity exceeding 120,000 euros.
\end{abstract}

Design/Methodology/Approach: The paper estimates a logistic regression model of firm auditor choice between an external auditor and the BSA which incorporates variables proxying for both agency conflict and organizational complexity effects.

Findings: Our results show that of the potential agency factors, only board independence drives auditor choice, whereas organizational complexity and risk factors including firm size, investment in inventories, subsidiary status and complexity drive auditor choice. These results may be explained in the administrative audit role of the BSA which both monitors day-by-day firm operations and the financial statements preparation 'project'. Stakeholders as a result are reassured that in general their interests are protected. Finally, we find that legal form and voluntary IFRS compliance exert an impact on auditor choice.

Originality/value: The paper provides support for an internal yet independent auditing body such as the Italian BSA as a wider model for corporate governance in European non-listed firms (OECD, 2004 and 2015). The BSA as an administrative and financial auditing body made up solely of independent highly qualified professionals can work within the firm on an operational basis, and in so doing can increase stakeholder protection.

Keywords: auditor choice; non-listed firms; agency conflicts; organizational problems; Italian environment.

JEL: M42.

Correspondence Address: Jon Tucker, Centre for Global Finance, University of the West of England, Frenchay Campus, Coldharbour Lane, Bristol BS16 1QY, UK. Email:

jon.tucker@uwe.ac.uk. 


\section{Auditor Choice in Italian Non-Listed Firms}

\section{Introduction}

In the academic literature, we can identify two main approaches to explaining the drivers of auditor choice. The first approach focuses on the reduction in information risk that accrues as an audit leads to more reliable reporting. Firms with higher agency costs are inclined to choose a high-quality auditor in order to strengthen their corporate governance and thereby alleviate potential agency conflicts (e.g. Francis et al., 1999; Gul and Tsui, 2001; Krishnan, 2003; Mansi et al., 2004; Fan and Wong, 2005; Knechel et al., 2008; Lin and Liu, 2009; Mahdavi et al., 2011; Niskanen, Karjalainen, and Niskanen, 2011). The second approach (e.g. Kneckel 2002; Kneckel et al., 2008; Liu and Lai, 2012) argues that high quality auditing also improves the operational efficiency and effectiveness of a firm through the evaluation of its internal processes, deterrence against management malfeasance, and increased compliance with legal and regulatory constraints. In this paper, we attempt to synthesize the two approaches by developing a model of the determinants of auditor choice in non-listed firms which incorporates variables proxying for both agency conflict and organizational complexity effects.

The EC Green Paper on Corporate Governance (EC, 2011) proposes the introduction of an Independent Professional Supervisory Board (IPSB) for SMEs (Zanardi, 2010), akin to the Italian Board of Statutory Auditors, as a corporate governance mechanism for listed and nonlisted European SMEs (OEC, 2010; Zanardi, 2010). The Paper (EC, 2011, p. 4) highlights that proper and efficient governance is also valuable for non-listed companies, especially taking into account the economic importance of such firms. Such firms are of particular importance in countries with less developed capital markets where the vast majority of firms are not listed on a stock exchange or regulated market. Even in more developed economies, most small and medium-sized enterprises are not listed. According to the OECD (2004), improved corporate governance within non-listed firms has the potential to significantly boost productivity growth and job creation in both developed and developing economies (Ecoda, 2010). Moreover, the OECD (2015, p. 10) highlights that a "credible corporate governance framework, supported by effective supervision and enforcement mechanisms, will help improve the confidence of domestic investors, reduce the cost of capital, underpin the good functioning of financial markets, and ultimately induce more stable sources of financing". However, despite their abundance and economic importance, the governance of non-listed firms is an often neglected area in corporate governance studies.

The OECD (2015, p. 11) further points out that the usefulness of the disclosed information in non-listed firms "...often depends on the experience and quality of the auditors". It posits that in non-listed firms both corporate governance and auditing are relevant concerns. The Chartered Accountants of Italy, Spain and France signed a document that supports this proposal (OEC, 2010). Therefore, the Italian context is of significant interest and relevance in the wider international context, due to the particularity of the Italian auditing and corporate governance environment that allows non-listed firms to be audited by the BSA, an independent statutory committee consistent with the 'traditional' model of corporate governance adopted by the vast majority of Italian firms (Mariani et al., 2010). Thus, for such firms, the BSA competes with external auditors in the market for auditing services. The role of an internal and independent professional auditing body such as the Italian Board of Statutory Auditors (the Collegio Sindacale) with administrative, and also potentially financial, auditor skills may address agency problems within a company. In the context of market globalization, corporate governance has gradually become more significant as a concern for small and medium-size entities as improvement here can increase 
competitiveness. Strengthening the governance structure is also a means to augmenting strategic management within such firms. Therefore, aspects of the corporate governance system for Italian firms may be useful to inform the wider EU debate on a corporate governance system for European (listed and) non-listed firms. More specifically, the administration and control system for Italian firms has proved to be a valid and effective model in general, and in particular in moments of crisis (ICG, 2011, p. 2). This system is based on the work of the general shareholders' meeting which has the power to pass resolutions, the board of directors (BoD) which conducts management duties, and the 'collegio sindacale' (an independent professional supervisory board or statutory committee, regulated by Italian company law, which includes professional auditors among its members) as the control body within the company's governance structure. The clear distinction between management (attributed exclusively to the BoD) and control (attributed to the BSA) is a fundamental feature of the model which aims to ensure, on one hand, freedom of choice in the operations necessary for the conducting of business activities and, on the other hand, to provide a continuous monitoring of these choices in relation to compliance with the law and the principles of correct administration, and in relation to the suitability of the organizational, administrative and accounting system and its correct functioning (ICG, 2011). Thus, focusing on the Italian context provides an important benchmark model for consideration in the wider international (and especially European) context.

The existing literature concerning auditor choice in non-listed firms (e.g. Carey et al., 2000; Chaney et al., 2004; Lennox, 2005; Fortin and Pittman, 2007; Broye and Weill, 2008; Knechel et al., 2008; Niskanen, Karjalainen, and Niskanen, 2011) shows results that vary across countries given different legal systems and degrees of investor/stakeholder protection.

Our motivation for studying auditor choice in non-listed firms in an Italian setting is as follows. First, most firms in Europe (and also in Italy) are non-listed firms with both family ownership and governance (Iacovone, 2015, Ecoda, 2010). Indeed, at the end of 2014 only 342 firms out to about 4.45 million were listed on the Italian Stock Exchange (Italian Stock Exchange, 2014). Moreover, approximatively $99.9 \%$ of Italian firms are smaller in size, and about the $94.4 \%$ of them are micro-sized (EC, 2013). Finally, $85 \%$ of these firms are familyowned (AIDAF, 2015; Osservatorio AUB, 2014). In theory, family ownership reduces potential manager-shareholder agency problems, and thus reduces the need for high quality financial information (Wang, 2006) and auditing. Secondly, Ball and Shivakumar (2005) find that (family and non-family) non-listed firms are more likely than listed firms to communicate privately with their stakeholders (e.g. shareholders, creditors, employees, suppliers), thereby reducing the demand for financial reporting quality. Non-listed firms are thus likely to substitute private communication for (public) financial reporting to reduce information asymmetry between managers and other parties (e.g. lenders, shareholders, customers). As a consequence, higher quality financial statements are demanded more by listed firms than by non-listed firms.

The literature also demonstrates that the choice of an auditor by the smallest (non-listed) firms is driven mostly by firm complexity, that is, the need for strengthening internal control (Kneckel et al., 2008; Niskanen, Karjalainen, and Niskanen, 2011). This means that the higher the complexity of the firm the greater the need for a high quality auditor in order to monitor firm complexity and operations. Inside the 'traditional' corporate governance model of Italian (listed and non-listed) firms, the Board of Statutory Auditors (BSA), that is a statutory committee engaged at the shareholders' meeting, considers among other factors the appropriateness of the procedures adopted by management in pursuing the objectives of the firm, and operates on a day-by-day basis (the administrative auditing function as discussed in section 2). Therefore, it is argued that an Italian non-listed firm, which requires its financial statements to be audited, is more likely to engage the statutory committee as financial auditor 
as such firms typically do not derive net benefits from engaging an external (high quality) auditor. Moreover, external audit companies tend to charge higher audit fees, commensurate with their reputational and industry specialization attributes (e.g. Ferguson et al., 2003; Choi et al., 2008; Francis and Wang, 2008), thus reducing the net benefit for a non-listed firm to have its financial statements audited by an external auditor (whether Big 4 or otherwise). Finally, our study contributes to the debate detailed in the EC Green Paper on Corporate Governance (EC, 2011). Our results show that an increase in board independence leads to an increase in the likelihood that a firm will engage an external auditor, the only agency factor we find to be significant. Surprisingly, family ownership concentration is not a significant determinant. From an organizational complexity and risk perspective, subsidiaries, larger firms, and firms with a larger investment in inventories have a greater likelihood of engaging an external auditor, whereas firms with greater complexity and higher receivables have a lower likelihood due to the role of a BSA in mitigating organizational complexity. Finally, we find that legal form plays a moderate role, whereby firms incorporated as a stock company are more likely to engage an external auditor, as are firms voluntarily adopting IFRS. Therefore, our findings suggest that agency issues and organizational firm complexity and risk at least partially explain the auditor choice in Italian non-listed firms.

The remainder of the paper is organized as follows. In section 2 we explain the Italian auditing environment. In section 3 we review the existing literature on auditor choice. We then explain the research design and methodology employed to develop the auditor choice model in section 4. Section 5 presents descriptive statistics for key model variables and goes on to analyze our empirical results. Finally, section 6 summarizes and concludes.

\section{The Italian Auditing Environment}

The Italian auditing environment is something of a special case compared to other European auditing regimes. While listed firms may be audited only by an external auditor, a Big 4 firm or otherwise, non-listed firms may instead choose to be audited by a Board of Statutory Auditors. Here we provide some context on the Italian auditing environment in order to understand the role of these statutory auditors.

Since 1998 there have been a series of legislative changes to the Italian auditing system. The 'Draghi Law' (Legislative Decree 24 February 1998, No. 58) was instituted in that year to separate the administrative audit from the financial audit in both listed and non-listed firms. The administrative auditors have to respect both laws and corporate by-laws, attend to the principles of correct management, and consider the appropriateness of the procedures adopted by management in pursuing the objectives of the firm. In addition, the administrative auditors are responsible for verifying the adequacy of the organizational structure of the firm, its internal auditing system, and its administrative accounting system. The auditors conduct the duties assigned to them in compliance with the law and the Governance Code. More specifically, the administrative auditors monitor and critically appraise the decisions adopted by the management of a firm, by, for example, participating in the meetings of the Board of Directors. Administrative auditors have to report their opinion to the annual shareholders' meeting on the 'correctness' of a firm's operations and the behaviour of its management.

In contrast, the financial auditors have to certify the correctness of the bookkeeping entries and the financial reporting of management operations in order to verify that the accounts are maintained appropriately, and that ultimately the annual reports give a true and fair view of the financial position, financial performance and cash flows of the company. Further, they supervise the financial disclosure process, the efficacy of the internal control systems, the internal auditing and risk management of the firm, the auditing of the annual accounts and of the consolidated accounts, and the independence of the external auditor (when appointed by 
the firm as financial auditor). The financial auditors comply both with Italian law and with International Standards on Auditing, and their work culminates in the issuance of the auditing report which provides an opinion on the reliability of the financial statements.

Following the Corporate Reform Law of 2003, the Italian Civil Code sets out three alternative models of corporate governance: traditional, monistic and dualistic, though the traditional model is that most used by Italian firms (Mariani et al., 2010). Under the 'traditional' model, which provides the focus for this paper, two bodies are appointed by the shareholders. The first is the Board of Directors (BoD) who are responsible for the management of the firm. The second is the Board of Statutory Auditors (BSA), a mandatory body in charge of administrative auditing in all stock corporations as well as in all limited liability companies with equity exceeding $€ 120,000$. The BSA is appointed for a term of three years, and consists of three to five independent, professional members whose skills and responsibilities are clearly set out in law. Members must participate in all meetings of both the Board of Directors and the shareholders in order to monitor the activities of the former and to ensure that no fraud or illegal acts occur. The activities of the BSA also extend to monitoring the internal control system of the firm, thereby representing at least some protection for stakeholders against managerial excess and ultimately firm failure. The system is based on a clear distinction between the administrative function (which concerns the management of the firm) and the internal control function (which concerns the BSA). This therefore ensures the continuous supervision of the management by an independent body which is both highly qualified and furnished with significant powers of intervention in order to protect the interests of both firm insiders and outsiders.

The requirements for the statutory auditors (BSA) are that they: (i) should be strictly independent; (ii) must act exclusively in the interests of the firm; (iii) are selected from an Official Register of Auditors maintained by the Italian Minister of Justice, which is composed of professionals (Chartered Accountants) with a qualification in auditing, managers of complex enterprises with at least three years' experience, as well as university professors of law or economics; and (iv) are required to have advanced professional skills and knowledge in the fields of accounting, auditing, finance, management and/or taxation.

Since 2003, the financial audit of Italian non-listed firms can be conducted by an external auditor or by the BSA. Table 1 provides further details of auditor requirements by type of company and corporate governance model. In particular, article 2409-bis of the Italian Civil Code specifies that stock or public companies (PCs) should in the first instance be audited by an external auditor (that is, the legal non-mandatory auditing system required for stock or public companies). Alternatively, the general shareholder meeting for such firms may decide to assign the financial auditing to the BSA. In this case, the BSA is in charge of both administrative and financial auditing. Further, art. 2477 of the Italian Civil Code specifies that all limited liability companies (Llcs) with equity exceeding $€ 120,000$, should in the first instance be audited by the BSA (that is, the legal non-mandatory auditing system required for Llcs). In this case, the BSA is in charge of both administrative and financial auditing. Alternatively, the general shareholder's meeting may decide to assign the financial auditing to an external auditor. The consequence of this apparently confusing regime is that any Italian non-listed firm may decide to assign their financial auditing to either the BSA or to an external auditor (Big 4 or otherwise firm). The administrative and auditing fees of the statutory auditors are defined at the shareholders' meeting or by the firm's by-laws (art. 2402 of Italian Civil Code).

\section{[Insert Table 1 here]}


In this paper we focus on the auditor choice of 'Type 2' companies, that is, non-listed stock companies and limited liability firms (limited liability firms cannot be listed in Italy) that are not publicly accountable, and are not obliged to prepare consolidated financial statements. Therefore, these firms have the choice of engaging either a BSA or an external auditor as financial auditor.

When the BSA is also appointed as financial auditor, it conducts both the administrative and financial auditing for a firm. Italian law prescribes to the members of the BSA the same level of independence as that enjoyed by external auditors. The Draghi Law both set out and reinforced the duties of the BSA more clearly, granting it the power to report any serious management irregularities to the Court.

In sum, the BSA is a multi-faceted, qualified and independent statutory body which represents a distinctive feature of the Italian traditional corporate governance model (Melis, 2004). Further, the BSA exerts pervasive power within the firm, in so doing protecting the shareholders by preventing fraud and monitoring the firm's operations. With regard to its performance of the control function, it should be noted that the BSA has the power and indeed the obligation to take part in company meetings, to convene its own meetings every 90 days or more frequently if desired, as well as to acquire from and exchange information with the directors, with the external auditor and with the controlling body of group companies. Furthermore, the shareholders may themselves report any irregularities directly to the BSA, thereby triggering a specific control activity (Art. 2409 Italian Civil Code). The BSA therefore places itself at the centre of a continuous flow of corporate information which enables it, both on its own initiative as a control body and through cooperation with other corporate bodies, to carefully monitor company management. As a consequence, the clear distinction between management (attributed exclusively to the $\mathrm{BoD}$ ) and control (attributed to a BSA) is a fundamental feature of the Italian "traditional" model of corporate governance. Thus model aims to ensure, on one hand, freedom of the choice of operations necessary for the carrying on of business activities and, on the other hand, continuous monitoring of these choices to ensure compliance with the law, the principles of correct administration, and the suitability of the organisational, administrative and accounting system as well as its correct functioning.

In general, external auditors are considered to be of higher quality when compared to the BSA. The Italian literature on audit quality (e.g. Mariani et al., 2010; Cameran and Prencipe, 2011) finds that a BSA provides a lower level of audit quality (measured by the magnitude of earnings management, which is higher in absolute value) than an external auditor, although Bisogno (2012) finds no evidence of this in manufacturing firms. Such evidence does not mean that a BSA is in any sense a 'worse' auditor, as Italian law requires BSA members to have high level professional skills.

\section{Auditor Choice in Non-Listed Firms}

\subsection{Determinants of Auditor Choice in Non-Listed Firms}

Jensen and Meckling (1976) suggest that the external auditing of financial statements provides a partial solution to the agency costs arising from the separation of ownership and control within organisations. Moreover, auditors play a fundamental corporate governance role as they certify the validity of the financial statements (Watts and Zimmerman, 1986). In this context, agency costs may be reduced by subjecting the financial information to verification by a third party before provision to the providers of finance. The latter are then able to employ that audited information to assess the risk of the firm, and lenders are able to write debt covenants based upon it. Agency theory suggests a link between auditor quality 
and information asymmetry reduction (Dechow et al., 2010). Auditor choice studies start from the proposition that the demand for high quality audit arises from the information asymmetry between managers and investors (Carey et al., 2000; Chaney et al., 2004; Broye and Weill, 2008; Niskanen, Karjalainen, and Niskanen, 2011). Thus, prior research uses agency theory to at least partially explain auditor choice (e.g. Carey et al., 2000). In the most narrow sense, the basic role of the audit is to improve the quality of the firm's financial statements, and there is significant evidence that a high quality audit reduces the incidence of earnings management (Becker et al., 1998; Francis et al., 1999; Knechel et al., 2008).

The literature further suggests that the demand for quality auditing depends on more than simply a cost of capital argument (Abdel-khalik, 1993; Knechel, 2002; Knechel et al., 2008) since an audit can support managers in improving the efficiency of a firm or in removing the information asymmetries in internal reporting through the evaluation of firm internal processes, deterrence against management malfeasance, and increased compliance with legal and regulatory constraints (Kneckel, 2002; Kneckel et al., 2008; Liu and Lai, 2012). In essence, the literature suggests that organizational complexity is associated with greater information asymmetry (e.g., Simunic and Stein, 1997; Bushman et al., 2004; Demirkan et al., 2011). Consistent with Kneckel et al. (2008), our study extends the existing literature on the determinants of auditor choice by examining whether the information asymmetry arising from organizational complexity affects the demand of complex firms for higher quality auditors.

If this is the case, an effective administrative auditor (such as the Italian BSA) positioned inside the corporate governance model adopted by the firm may reduce the organizational complexity of the firm, even if a BSA is considered a 'lower' (financial) auditor compared to external auditors. Considering that the financial statements of (family and non-family) nonlisted firms, when compared to listed firms, are not scrutinized as much by investors, financial analysts or others (e.g. they are not examined at all by stock exchange regulating authorities), non-listed firms most likely have less interest in engaging high quality auditors to provide high quality information to outsiders. Thus, it is argued that, given its administrative auditing role, a BSA is capable of addressing both the agency and organizational problems facing non-listed firms.

A considerable number of studies examining factors affecting auditor choice focus on firmspecific characteristics including firm size, leverage, and business complexity (e.g. Copley and Douthett, 2002; Broye and Weill, 2008; Knechel et al., 2008). Other studies investigate the influence of corporate disclosure (Lee et al., 2003), board characteristics (Beasley and Petroni, 2001; Lin and Liu, 2009), and the audit committee (Abbott and Parker, 2000). With respect to ownership structure as a key corporate governance mechanism, the existing literature examines whether different ownership types are associated with auditor choice. Given the international prevalence of ownership concentration through family control, the relationship between family control and auditor choice is examined by El-Ghoul et al. (2007), Francis et al. (2009), Niskanen et al. (2010), and Niskanen, Karjalainen, and Steijvers (2011). As our sample firms includes family firms, we investigate the influence of this ownership structure on the auditor choice.

The remainder of this paper examines the determinants of auditor choice in Italian nonlisted firms, drawing upon the two approaches employed in the existing literature: the agency conflict approach and the organisational complexity approach.

\subsubsection{The agency conflict approach}

In this section we analyze the key agency conflicts between non-listed firms and their stakeholders with reference to the existing literature. The foundation on which most family 
firm studies are built is the agency conflict framework. The unique characteristics of family firms affect the nature and extent of agency problems. The effect of family ownership on earnings quality in listed firms is controversial and is explored through two conflicting agency problems: the type I agency problem, the classic owner-manager conflict, and the type II agency problem, the conflict between controlling and non-controlling shareholders (Ali et al., 2007; An, 2015). If we consider the type I agency problem, family owners have a strong monitoring incentive to maintain their wealth as longer-term investors. The family can reduce agency problems between owners and managers by placing one of their members in the position of the manager (Anderson et al., 2003). For the type II agency problem, as family shareholdings increase, family managers become less constrained by disciplinary forces and are more entrenched, and thus higher family ownership can give rise to lower earnings quality which in turn requires only a lower quality auditor (An, 2015). In fact, Ali et al. (2007) find that, compared to listed non-family firms, listed family firms face less severe agency problems from the separation of ownership and management, but more severe agency problems that arise between controlling and non-controlling shareholders.

However, important differences exist between non-listed and listed firms in both corporate governance terms and the contracting incentives to provide high quality financial information through high quality audit. Thus, the empirical evidence for listed family firms does not necessarily extend to non-listed family firms (Beatty et al., 2002; Ball and Shivakumar, 2005). We argue that the accounting quality of non-listed family firms is not only driven by the typical (Type I and II) agency problems documented in listed firms but also by the specific agency problems of non-listed firms relating to influential stakeholders. As the key/influential stakeholders of Italian non-listed (family or otherwise) firms are banks (Vinciguerra and Cipullo, 2009; La Rocca and Montalto, 2012), we argue that a different motivation for audit quality arises from the bank-firm relationship.

\section{Ownership variables}

\section{a) Ownership concentration, foreign ownership and board independence}

Evidence on the relationship between ownership concentration and auditor choice is provided in the prior empirical literature, though it concerns mainly listed firms. Fan and Wong (2005) find that firms subject to greater agency problems associated with higher ownership concentration are more likely to hire Big $\mathrm{N}$ auditors, thereby supporting the view that the large audit firms can enhance the confidence of capital market investors. In companies with concentrated ownership, large shareholders can affect the firm's management, especially when they become board members. Hu and Izumida (2008) argue that ownership concentration has an impact on corporate performance. Chen et al. (2007) argue that the audit service demanded by firms with controlling shareholders may be different from that demanded by firms without controlling shareholders, and find that audit quality deteriorates and is compromised when an auditor is engaged by a family-controlled business client. This negative association is also found by El-Ghoul et al. (2015), who study 13 Western European countries, and by Copley and Douthett (2002), Francis et al. (2009), and Darmadi et al. (2012), who analyze the association between ownership concentration and the probability of hiring large audit firms in the US, France, and Indonesia. Lin and Liu (2009) show that Chinese firms with greater ownership concentration are less likely to hire Big N auditors. Further, Dong and Zhang (2008) find for listed Chinese firms that the propensity of external auditors to qualify is lower, the higher the concentration of shares or the lower proportion of public shares. Family ownership and governance are widespread, both among privately held companies, but also among publicly traded firms (Bukart et al., 2003; Morck and Yeung, 2004). The literature confirms that family firms are prevalent in Italy as a 
corporate form (e.g. Cascino et al., 2010; La Rocca and Montalto, 2012). Ang et al. (2000) argue that agency conflicts necessitate the monitoring of management in non-listed firms as such firms are not always run by owner-managers. Consistent with the literature, and in particular with Ali et al. (2007), Niskanen, Karjalainen, and Niskanen, (2011) and An (2015), we argue that non-listed firms with greater family ownership concentration have less incentive to engage a high quality auditor (an external auditor) because of the type II agency problem, that is, the conflict between majority and minority shareholders. In particular, Niskanen, Karjalainen, and Niskanen (2011) find that audit quality, in terms of selecting Big 4 auditors, is demanded by non-listed firms for the purpose of addressing the loss of control of outside shareholders as a result of ownership dispersion. Moreover, Francis et al. (2009) investigate the demand for audit quality in a sample of French listed firms, and find that the demand for audit quality decreases with an increase in ownership concentration and inside family ownership. Niskanen et al. (2010) show similar results for Finnish non-listed family firms. Therefore, consistent with this literature, we investigate whether family ownership also influences auditor choice in non-listed firms.

In addition to ownership concentration, family control may also play an important role in either exacerbating or mitigating agency problems between the controlling family and other shareholders (Darmadi, 2012). As suggested by Steijvers et al. (2010), family-controlled firms are more vulnerable to agency problems. Firstly, since it has effective control of the firm and assigns its members to sit either on the board or management team, the controlling family may have greater opportunity for extracting private benefits and lower corporate transparency. Thus, family firms may be reluctant to impose external monitoring and are more likely to engage low-quality auditors to protect the family's private interests (Niskanen, Karjalainen, and Steijvers, 2011). Secondly, and conversely, family firms are concerned somewhat more than other firms about their long-term survival and reputation, leading them to provide high-quality financial information to maintain investors' confidence (Dey et al., 2011). This may lead to the appointment of high-quality auditors. Finally, Darmadi, (2012) find that there is a strong positive association between ownership concentration and the demand for Big 4 auditors, contrasting the findings of many single-country studies which find a negative relationship. A positive relation may imply that when the proportion of shares held by the largest shareholder increases, firms are more aware of agency issues, thus leading them to engage higher-quality auditors in order to set in place an additional monitoring function; high-quality audits may then be used to mitigate the agency issues that arise between the controlling shareholder and minority shareholders. However, when the controlling shareholder is a family, the association between ownership concentration and the demand for high-quality auditors becomes negative, suggesting that family-controlled firms are significantly less likely to have their financial statements audited by Big 4 auditors. Thus family-controlled firms are less likely to experience information asymmetry problems as firm ownership and control are less separated, leading to a lower demand for high-quality auditors. La Rocca and Montalto (2012) argue that in Italy type II agency problems are relevant. Larger shareholders may use their position to extract private benefits of control at the expense of minority shareholders. In particular, if the largest shareholder is an individual or a family, as in Italy, then they have a significant incentive to expropriate (Villalonga and Amit, 2006). In our paper, we employ a dummy variable $(O W N)$ which takes a value of 1 if at least $50 \%$ of the voting rights or outstanding shares are held by a family, and takes the value of 0 otherwise, consistent with the approach of Cascino et al. (2010), providing a more granular distinction between family-owned companies and firms with other major block holders (nonfamily-run firms). The following hypothesis is thus proposed: 
H1a. The probability that an Italian non-listed firm assigns financial auditing to an external auditor decreases as family ownership concentration increases.

\section{b) Foreign shareholders}

Karim et al. (2013), analysing the auditor choice of emerging market IPO firms, find that foreign shareholders tend to trade-off the increased monitoring costs of engaging a higher quality auditor with information asymmetry agency costs. Van Zijl and Karim (2010) find that the foreign shareholders of listed firms have more incentive to assign financial auditing to high quality auditors as they are concerned about financial statement information quality and wish to protect their investment. Thus, as we determined in the previous section there is evidence that listed firms prefer a high quality (external) auditor as the proportion of foreign ownership $(F O W N)$ increases, though for non-listed firms there is a paucity of evidence. Consistent with the literature for listed firms, we propose the following hypothesis:

H1b. The probability that an Italian non-listed firm assigns financial auditing to an external auditor increases as the degree of foreign share ownership increases.

\section{c) Board independence}

The separation of ownership and control increases agency conflicts within the firm (Jensen and Meckling, 1976) and thereby increases the need for management monitoring (Fama, 1980; Fama and Jensen, 1983; Ang et al., 2000). The literature suggests that firms with more independent boards tend to commit less financial statement fraud (Beasley, 1996) and generate lower discretionary accruals (Dechow et al., 1996; Peasnell et al., 2000; Xie et al., 2003; Jaggi et al., 2009) than firms with less independent boards. However, the empirical evidence is mixed.

Niskanen, Karjalainen, and Niskanen (2011) find that the probability of non-listed firms engaging a Big 4 auditor decreases as CEO ownership increases. Thus, firms with a weaker internal corporate governance mechanism (e.g. high ownership concentration) are inclined to choose a low-quality auditor so as to capture and sustain the gains to their opaqueness. Mengoli et al. (2009, p. 7) suggest that the dominant role of large shareholders, which extends even to the Board of Directors, leads to a system characterized by "weak managers, strong block holders and unprotected minority shareholders". Family control has been identified as the harbinger of both benefits and costs (Favero et al., 2006). However, in the Italian context, characterized by concentrated family ownership, it is possible that directors classified as independent may not be independent in substance at all (Prencipe and BarYosef, 2011). In this context, it is difficult to predict the sign of association between board independence and auditor choice (e.g. Beasley and Petroni, 2001). In this study, we employ a dummy variable $(B O A R D)$ which takes a value of 1 if more than $50 \%$ of the voting rights belong to the managers, and the value of 0 otherwise. To address the uncertainty in this relation, we propose the following non-directional hypothesis:

H1c. The probability that an Italian non-listed firm assigns financial auditing to an external auditor is associated with the degree of board independence.

\section{External characteristics and relations of the firm}

\section{a) International activities}

Firms with a strong international presence are more likely to engage a high quality auditor as such auditors are better able to tackle the constraints presented by geographical dispersal and to capture the benefits from specialized correspondents in local legislatures who can make 
on-site visits at relatively low cost (Piot, 2005). Chaney et al. (2004) find that firms making foreign sales require the services of auditors with international business expertise. In this paper we employ the proportion of sales made outside the country of origin (FSALES) as a proxy for the degree of internationalization, and we propose the following hypothesis:

\section{H2. The probability that an Italian non-listed firm assigns financial auditing to an external auditor increases with the degree of internationalization.}

\section{b) Leverage}

Seminal studies of leverage such as Fama and Miller (1972) and Jensen and Meckling (1976) find that the severity of the agency conflict increases with the proportion of debt in a firm's capital structure. A firm requiring new financing will want to strengthen the credibility of its financial statements by engaging a high quality auditor. Higher quality auditing is required by the creditors for monitoring or by the shareholders to signal financial information credibility (Blackwell et al., 1998; Bharat et al., 2006; Fortin and Pittman, 2007; Knechel et al., 2008). Knechel et al. (2008) find that auditor choice in Finnish firms is driven by firm financing requirements. Management has an incentive or even compulsion to signal financial statement credibility to creditors by engaging a highly qualified auditor (e.g. Carey et al., 2000). Existing studies find that the availability of new financing depends on the riskiness of the firm (Knechel et al., 2008), and that improved disclosure reduces investor risk (Botosan, 1997). However, Niskanen, Karjalainen, and Niskanen (2011) find evidence for Finnish nonlisted firms that shareholder-manager agency conflicts reduce the demand for audit quality as leverage increases, as leverage aligns manager-shareholder incentives and reduces the need for monitoring. Further, Fortin and Pittman (2007) observe that auditor choice affects neither the yield spread nor the credit rating of US non-listed firms, while Broye and Weill (2008) find that the impact of leverage on auditor quality varies across countries. According to Niskanen, Karjalainen, and Niskanen, (2011), the existing literature suggests that the equity ownership structure of a firm affects the manager-shareholder conflict, and therefore the agency costs related to this information asymmetry. When managers' stockholdings increase, management becomes more likely to make decisions consistent with the best interests of other stockholders, and at the expense of bondholders or other uninformed stakeholders. This suggests that as managerial share ownership increases, shareholder-manager agency costs initially decrease and shareholder-creditor agency costs increase. In other words, agency conflicts related to the shareholder-creditor agency relationship imply that an increase in financial leverage should increase the demand for audit quality. Higher quality auditors could be engaged by the owners to signal the credibility of the firm's financial information, or by creditors for the purposes of monitoring the firm. To mitigate agency problems, controlling owners may employ different monitoring and bonding mechanisms to assure minority shareholders that their interests are protected (Fan and Wong, 2005). According to Niskanen, Karjalainen, and Niskanen (2011), the same idea can be extended to other stakeholders such as creditors (e.g. lenders), and thus monitoring and bonding mechanisms are also important for smaller, non-listed firms. Therefore, it may be argued that such firms have an incentive to engage a more credible, high quality auditor when managerial ownership (that is family ownership) decreases. Thus, it is argued in our study that in non-listed firms with family control, high quality auditors present more value to shareholders than to creditors.

We measure leverage ( $L E V)$ as the ratio of total financial debt (the sum of debt to banks, other capital providers, and bondholders) to total assets. Importantly, Ball and Shivakumar (2005) find that non-listed firms tend also to rely heavily on financing through trade credit which constitutes a form of 'free' financing. We thus construct a measure for the growth in trade accounts payable ( $A P G R O W)$ to proxy for a reduction in the need for new external 
finance: as accounts (trade) payables increase, free financing increases, and the requirement for new financing should be reduced. Effectively, accounts payables substitute for leverage. $A P G R O W$ is defined as the relative change in accounts payable for the year. Consistent with agency theory (Jensen and Meckling, 1976) which posits that agency costs increase with the proportion of outside financing of the firm, we expect auditor choice to be positively related to both $L E V$ and $A P G R O W$ and we propose the following hypothesis:

H3. The probability that an Italian non-listed firm assigns financial auditing to an external auditor increases as leverage and the accounts (trade) payable growth rate increase.

\subsubsection{Organisational complexity and the audit risk approach}

\section{Firm internal characteristics and relations}

Jensen and Meckling (1976, p. 59) hypothesize that agency costs increase with firm size "because it is likely that the monitoring function is inherently more difficult and expensive in a larger organization". Further, it is argued that there is more wealth at risk in larger firms, which also increases agency costs (Abdel-Khalik, 1993). Simunic and Stein (1987) and Abbott and Parker (2000) hypothesize a positive relationship between client firm size and the quality of audit firms chosen, arguing that client size is a critical indicator of the extent of client agency costs. Similarly, larger clients may have become accustomed to superior services from a myriad of professional advisors, and thus they may be less satisfied with the services of small audit firms. Furthermore, bigger clients may require the additional professional services, such as consultancy, tax and legal services, which are more likely to be supplied by (external) larger audit firms (Aksu et al., 2007). Larger firms are therefore predicted to be more likely to engage a high quality auditor (that is, an external auditor). Firm size is therefore considered a proxy for increased agency costs and a greater need for monitoring (Broye and Weill, 2008). In our study, we measure firm size (SIZE) as the logarithm of total assets. Consistent with the existing literature, we propose the following hypothesis:

H4a. The probability that an Italian non-listed firm assigns financial auditing to an external auditor increases as firm size increases.

A high quality auditor may help managers to improve firm efficiency and effectiveness, especially as the firm grows. However, as a firm grows it becomes more complex and difficult to control (Kinney and McDaniel, 1989). Firms with greater asset, operational, financial, and transactional complexity will benefit in particular from a high quality auditor (Newton and Ashton, 1989; Knechel et al., 2008). Abdel-Khalik (1993) finds evidence of increased oversight difficultly for the owners of growing non-listed firms. Thus, more complex firms have a greater incentive to choose a high quality auditor (Simunic and Stein, 1987; Abdel-Khalik, 1993; Hay and Davis, 2004; Knechel et al., 2008). As discussed in section 2, the role of the BSA as administrative auditor in the traditional corporate governance model of Italian firms is to respect both laws and corporate by-laws, to attend to the principles of correct management, to verify the appropriateness of administrative, organizational and accounting patterns, and also to pay attention to the procedures adopted by management in pursuing the objectives of the firm. As a consequence the administrative auditor ensures the continuous and simultaneous supervision of management in the capacity of an independent body which is both highly qualified and furnished with significant powers of intervention. This structural characteristic is markedly different from that adopted in other 
countries where there is no such clear role and responsibility distinction between the officers that administrate and those that perform control functions. Thus, understanding the strong control of the administrative auditor (BSA), and in contrast to the existing literature, we propose the following hypothesis:

H4b. The probability that an Italian non-listed firm assigns financial auditing to an external auditor decreases as firm complexity increases.

We use two measures to gauge the complexity of the firm. Firstly, as we are unable to measure the length of the chain of control directly due to data constraints, we instead employ the ratio of total annual salaries paid to total operating expenses (SALARY), consistent with Knechel et al. (2008). Secondly, following Knechel et al., we gauge complexity (COMPLEX) as the sum of property, plant and equipment, inventory and receivables, scaled by total assets. This second measure reflects the asset and transactional complexity of the firm, consistent with Stice (1991) and Hay et al. (2006).

Ge and McVay (2005) argue that many disclosed material control weaknesses are due to problems in subsidiaries. Knechel et al. argue that firms are more likely to be audited by an external auditor when they are themselves subsidiaries of larger entities, as a parent will extend its financial auditing system to all of its subsidiaries to ensure effective monitoring. In our study, we employ a dummy variable (GROUP) to reflect the subsidiary status of the firm which equals 1 if the firm belongs to a group, and 0 otherwise. We propose the following hypothesis:

H4c. The probability that an Italian non-listed firm assigns financial auditing to an external auditor increases where it is the subsidiary of a larger parent company.

We examine the association between measures of firm risk (and thus auditing complexity) and the demand for external, high quality audit. Poorly performing firms have an incentive to manipulate performance (Rogers and Stocken, 2005), and may therefore wish to signal that they have not resorted to earnings management by engaging a high quality auditor. Nonlisted firms with higher proportions of receivables and inventories may seek to obtain validation of these balances for the benefit of stakeholders such as suppliers (Dedman et al., 2014). Simunic (1980) notes that such assets are difficult to audit, requiring observation and confirmation, thereby increasing auditor liability exposure. Similarly, creditors will take comfort when observing higher levels of balance sheet cash. However, non-listed, cash-based businesses present problems of verifiability (Godwin and Freedman, 1993). Thus, higher levels of inventory, receivables, and cash can lead to increased audit cost and riskiness, though greater value to the firm through independent (external) auditor verification. Finally, consistent with Knechel et al. (2008), we focus on the percentage growth in firm sales (SALEGROW) on the basis that rapid growth can lead to stressed or broken internal processes and increase firm complexity and riskiness (Kinney and McDaniel, 1989). However, given the strong control of the administrative auditor (a BSA), highlighted above in hypothesis $H 4 b$, and in contrast with the existing literature, we propose the following hypotheses:

H4d. The probability that an Italian non-listed firm assigns financial auditing to an external auditor decreases as sales growth and the balances of receivables, inventories, cash and cash equivalents increases.

Consistent with Dedman et al. (2014), we measure the riskiness of a firm's audit by means of three measures: inventories (INV), receivables (REC), and cash and cash equivalents 
$(C A S H)$, all scaled by total assets. Further, SALEGROW is measured as the relative change in sales.

Finally, we argue that younger firms may present greater audit risk due to increased information asymmetry (Diamond, 1989; Rajan and Zingales, 1998), thereby increasing their demand for an external independent auditor. Further, Pittman and Fortin (2004) find that the value of audit assurance to newly public companies is higher in terms of borrowing costs than for older firms which have a long history. Thus, as firms build a credit reputation through time, the monitoring value of the audit is reduced. We therefore expect to observe a negative relationship between age in non-listed firms and the likelihood of engaging an external auditor. We propose the following hypothesis:

H4e. The probability that an Italian non-listed firm assigns financial auditing to an external auditor decreases as firm age increases.

Consistent with Dedman et al. (2014), we gauge firm reputation as the natural logarithm of the firm's length of establishment in years $(A G E)$.

\section{Control variables}

We include a number of control variables. We argue above that a firm may have an incentive to engage a low quality auditor (a BSA) to potentially disguise its true profitability. Dedman and Lennox (2007) point out that more profitable firms have an incentive to conceal proprietary information, suggesting that they may also wish to engage low quality auditors. We measure profitability in terms of the return on assets $(R O A)$ and expect a negative relationship. When analyzing the demand for audit quality in terms of the choice of a BSA or an external auditor, we also control for firm legal form (LEGFORM) whereby the firm is invited by the Italian civil code to use the BSA as a priority (for an Llc) or an external auditor (for a PC). Consistent with Broye and Weill (2008) and Niskanen, Karjalainen, and Niskanen, (2011) we expect a positive relationship. This variable takes the value 1 if the firm is incorporated as a stock company, and the value zero if incorporated as a limited liability firm. We include an industry classification dummy (IND) to assess if industry type has an impact on auditor choice, with the dummy taking the value of 1 for manufacturing firms, and zero otherwise.

To capture differences in parent company nationality, we include the variable NAT to take the value 1 where the parent is non-Italian, and zero otherwise. Here, we argue that a subsidiary is more likely to engage an external audit firm where the parent is non-Italian as: (i) non-Italian firms may only choose between a Big 4 or non-Big 4 external auditor; and (ii) a foreign parent company is less familiar with (subsidiary) Italian national accounting regulation. Finally, we account for the voluntary adoption of IFRS (IFRS) which may result from engaging a Big 4 audit firm. Such firms offer an international network of IFRS specialists and a track record in supporting IFRS transition (Hail et al. 2010). Thus we expect that firms complying voluntarily with IFRS in the preparation of their financial statements are more likely to choose a Big 4 (external) auditor because of the international auditing expertise of the latter. Thus, in this case the engagement of a high quality auditor is a consequence of IFRS adoption. The control variable IFRS takes the value 1 if the firm voluntarily adopted IFRS, and zero otherwise. 


\section{Research Methodology and Sample Selection}

Our accounting, financial market and corporate governance data are collected from the Bureau van Dijk AIDA Database in 2011, at which time the year 2009 is the latest available. The data population is composed of Italian non-listed firms which are 'firms that do not have public accountability', are not obliged to prepare consolidated financial statements, and which have equity capital exceeding $€ 120,000$. We exclude financial industry firms due to their non-standard financial statements and regulatory status, consistent with existing studies. In total, 52,418 firms meet our sample selection criteria, that is, firms faced with the choice of assigning their financial auditing either to a BSA or an external auditor. From this body of firms we extract a random sample of 384 firms, consistent with the approaches of Kreicie and Morgan (1970), as many of the data items must be collected by hand.

Table 2 shows the distribution of firms by auditor type. 74\% (284) of sample firms assign their financial auditing to a BSA, while only $26 \%$ (100) sample firms choose an external auditor. 108 firms (28\%) are non-listed stock companies, and of these 62 firms (57\%) assign their financial auditing to a BSA, with the remaining 46 firms (43\%) audited by an external auditor. However, $276(72 \%)$ firms in our sample are limited liability firms, and of these 222 firms $(80 \%)$ are audited by a BSA, while $54(20 \%)$ assign their financial auditing to an external auditor.

\section{[Insert Table 2 here]}

We estimate a logistic regression model, as given in Equation 1, with the dependent variable $A U D I T$ defined as a dichotomous variable which equals 1 if the firm is audited by an external auditor, and 0 where firm auditing is undertaken by the BSA.

$$
\begin{aligned}
& \operatorname{Prob}(\text { AUDIT }=1)= \\
& \alpha_{i}+\beta_{1} \text { OWN }_{i}+\beta_{2} \text { FOWN }_{i}+\beta_{3} \text { BOARD }_{i}+\beta_{4} \text { FSALES }_{i}+\beta_{5} L E V_{i}+ \\
& \beta_{6} \text { APGROW }_{i}+\beta_{7} \text { SALEGROW }_{i}+\beta_{8} \text { SALARY }_{i}+\beta_{9} \text { COMPLEX }_{i}+\beta_{10} \text { SIZE }_{i}+ \\
& \beta_{11} \text { GROUP }_{i}+\beta_{12} I_{N}+\beta_{13} \text { REC }_{i}+\beta_{14} \text { CASH }_{i}+\beta_{15} \text { AGE }_{i}+\beta_{16} N A T_{i}+ \\
& \beta_{17} \text { IFRS }_{i}+\beta_{18} \text { ROA }_{i}+\beta_{19} \text { LEGFORM }_{i}+\beta_{20} I_{N}+\varepsilon_{i}
\end{aligned}
$$

Where: $A U D I T=$ auditor choice dichotomous variable; $O W N=$ family ownership concentration dummy; FOWN = degree of foreign ownership dummy; BOARD = directors' independence dummy; FSALES = degree of foreign sales; $L E V=$ leverage ratio; $A P G R O W=$ account payables growth rate; $S A L E G R O W=$ sales growth rate; $S A L A R Y=$ salaries to total expenses; COMPLEX = firm organizational complexity variable; $S I Z E=$ natural logarithm of total assets; GROUP = subsidiary status dummy; $I N V=$ inventories to total assets; $R E C=$ receivables to total assets; $C A S H=$ cash and cash equivalents to total assets; $A G E=$ natural logarithm of firm age; $N A T=$ parent company nationality dummy; IFRS = voluntary adoption of IFRS dummy; ROA = return on assets ratio; LEGFORM = legal form dummy; $I N D=$ industry type dummy; and $\varepsilon=$ model error term.

Table 3 provides detailed definitions of the independent variables, along with a summary of expected coefficient signs and associated hypotheses.

[Insert Table 3 here] 


\section{Results}

Table 4 reports statistics for model dummy variables for firms audited by the BSA in Panel A and firms audited by an external auditor in Panel B. Table 5 reports descriptive statistics of the continuous study variables by auditor type.

\section{[Insert Tables 4 and 5 here]}

We commence our analysis by examining the factors related to agency conflicts first and then considering the factors which proxy for the size and the organizational complexity of the firm. 64\% of the firms audited by a BSA have close (family) ownership $(O W N)$, a pattern which contrasts with firms audited by an external auditor, $82 \%$ of which have dispersed ownership. Thus, an increase in ownership dispersion increases the probability of assigning financial auditing to an external auditor to counter reduced shareholder control over management. Only $10 \%$ of firms which engage a BSA have foreign shareholders $(F O W N)$, whereas a much higher $45 \%$ of firms engaging an external auditor have foreign shareholders. $66 \%$ of firms audited by a BSA are characterised by low board independence (BOARD), while $82 \%$ of firms audited by an external auditor have largely independent boards. Thus, on a prima facie basis, greater board independence tends to increased firm demand for external auditors. Neither BSA audited nor externally audited firms appear to be international in focus, with international sales to total sales (FSALES) of around only $10 \%$ in each case. Moreover, firms audited by an external auditor are somewhat more leveraged (LEV) than firms audited by a BSA, with leverage ratios of around $18 \%$ and $14 \%$, respectively. The accounts payable growth ratio $(A P G R O W)$ of $7 \%$ for BSA audited firms is higher than the $1 \%$ contraction for those firms audited by an external auditor. Thus we may infer that BSA audited firms appear to have a significant need for new finance on the basis of these proxies ( $L E V$ and $A P G R O W$ ). Externally audited firms appear to have a significant need for new finance on the basis of the leverage alone.

In terms of proxies for firm organizational complexity, we observe that annual salaries to total operating expenses (SALARY) is broadly invariant across the auditor types, with a ratio of $17 \%$ for firms audited by a BSA and $18 \%$ for firms audited by an external auditor. When organizational complexity is proxied by asset intensity (COMPLEX), we find it to be markedly higher in firms audited by a BSA $(50 \%)$ than in firms audited by an external auditor (41\%). Finally, when organizational complexity is proxied by revenue growth (SALEGROW), we find that it is markedly higher in firms audited by a BSA $(4.4 \%)$ than in firms audited by an external auditor (2.3\%). BSA audited firms thus grow more rapidly than externally audited firms, which may lead to internal process stress, increasing firm complexity and risk. Firms audited by a BSA tend to be smaller (SIZE) than their externally audited counterparts, with a natural logarithm of total assets of 9.7 compared to 10.5, respectively. In sum, organizational complexity is not clearly linked to auditor choice in terms of labor measures, though more complex firms in terms of asset intensity and rapid growth prefer a BSA to an external auditor, a result consistent with our expectations.

Subsidiary status (GROUP) appears to influence auditor choice as $78 \%$ of externally audited firms belong to a wider economic group compared to only $32 \%$ of BSA audited firms. With regard to parent company nationality $(N A T)$ we find that $90 \%$ of firm parent companies audited by a BSA are Italian, compared to only $42 \%$ for firms audited by an external auditor. Thus, sample firm parent companies are predominantly Italian and hence are more likely to be audited by the statutory committee.

In terms of voluntary IFRS adoption (IFRS), only a single firm $(<1 \%)$ audited by a BSA prepares its statements according to IFRS, while five firms (5\%) audited by an external 
auditor do so. With regard to industry type (IND), we observe that the majority of BSA audited $(65 \%)$ and externally audited $(66 \%)$ firms are manufacturers. There are significant differences in firm profitability $(R O A)$ across auditor types, with firms audited by a BSA exhibiting an ROA of $2.97 \%$ while firms audited by an external auditor enjoy a higher return of $3.81 \%$. The legal form ( $L E G F O R M)$ variable reveals that a much higher proportion $(46 \%)$ of firms audited by an external auditor are incorporated as a stock company than firms audited by a BSA $(22 \%)$.

Table 6 presents the correlation matrix for our model variables. A positive (negative) correlation here implies that an increase (decrease) in a given variable leads to firms choosing an external auditor (BSA). A Spearman (Pearson) correlation was computed to assess the association between the dependent and independent variables, with Spearman (Pearson) correlation coefficients above (below) the diagonal line. The Spearman correlation is a nonparametric test which measures the strength and direction of association between two variables that are measured on an ordinal or continuous scale and its associated correlation coefficients are denoted below by the symbol $r_{s}$. It is a useful test for cases when a Pearson correlation cannot be computed due, for example, to discrete variables being used. The Spearman correlation shows that there is a weak positive correlation between auditor choice $(A U D I T)$ and FOWN $\left(r_{s}=0.387, p=0.000\right)$, SIZE $\left(r_{s}=0.260, p=0.000\right), N A T \quad\left(r_{s}=0.359\right.$, $p=0.000)$ and LEGFORM $\left(r_{s}=0.236, p=0.000\right)$. We find that there is a moderate positive correlation between AUDIT and BOARD $\left(r_{s}=0.421, p=0.000\right)$ and GROUP $\left(r_{s}=-0.406\right.$, $p=0.000)$, a moderate negative correlation between $A U D I T$ and $O W N\left(r_{s}=-0.402, p=0.000\right)$ and a very weak negative correlation with COMPLEX $\left(r_{s}=-0.147, p=0.004\right)$. The Pearson correlation matrix shows a moderately significant positive correlation between auditor choice $(A U D I T)$ and the variables FOWN $(r=0.387, p=0.000), B O A R D(r=0.421, p=0.000), S I Z E$ $(r=0.309, p=0.000)$, GROUP $(r=0.406, p=0.000), N A T(r=0.359, p=0.000)$ and LEGFORM $(r=0.236, p=0.000)$. We also find a small positive correlation between AUDIT and IFRS ( $r=0.164, p=0.001$ ) which may be explained by the very small number of non-listed firms that adopted voluntarily to comply with IFRS. Finally, we find a moderate negative correlation between AUDIT and the variable $O W N(r=-0.402, p=0.000)$ and a moderate negative correlation with the variable COMPLEX $(r=-0.154, p=0.003)$. To test for potential multicollinearity problems we compute though do not report variance inflation factors (VIFs) but find that the statistics are substantially below the threshold of 10 for all variables.

\section{[Insert Table 6 here]}

Table 7 presents the results of our model of auditor choice in Italian non-listed firms. The dependent variable takes a value of 1 where a firm chooses an external auditor and 0 when it chooses a BSA. The independent variables are grouped by type to highlight the impact of: (i) agency factors; (ii) organizational complexity factors; and (iii) control variables.

\section{[Insert Table 7 here]}

We commence our discussion here with the agency factors. Family ownership concentration $(O W N)$ evidences a negative relation as expected, though is insignificant. This finding may be explained by the prevailing type II Agency Problem (Ali et al., 2007). Thus, as family shareholdings increase, family managers become less constrained by disciplinary forces and more entrenched, and higher family ownership can give rise to lower earnings quality (An, 2015), thereby leading to a reduced requirement for high financial auditor quality (Van Tendeloo and Vanstraelem, 2008). Thus, hypothesis $H 1 a$ is not supported as family ownership concentration does not drive auditor choice, consistent with Niskanen, 
Karjalainen, and Niskanen, (2011). The foreign ownership (FOWN) dummy has a positive coefficient, as expected, though is insignificant, perhaps as only $19 \%$ of sample firms have at least one foreign owner. Consistent with Karim et al. (2013), foreign shareholders tend to trade-off the increased monitoring costs of engaging a higher quality auditor with information asymmetry agency costs. Thus, hypothesis $H 1 b$ is not supported as foreign ownership does not drive auditor choice, a result which is inconsistent with Van Zijl and Karim (2010). Board independence $(B O A R D)$ is significantly positively related to auditor choice at the $5 \%$ level, and thus increasing board independence leads to a greater likelihood of engaging an external auditor. This finding suggests that greater board independence mitigates family influence in firms with concentrated family ownership, and so engage a high quality auditor in order to signal the quality of earnings. Thus, hypothesis $H 1 c$ is supported and we are able to confirm the otherwise uncertain coefficient sign as positive in the Italian context.

The coefficient for the foreign revenues variable (FSALES) is negative, though insignificant, a finding inconsistent with the existing literature, and thus hypothesis $\mathrm{H} 2$ is not supported. This finding is inconsistent with Piot (2005) and Chaney et al. (2004), where both studies find evidence that internationalization tends to lead to the choice of a high quality auditor. The coefficient of the leverage ratio variable $(L E V)$ is positive though insignificant. Thus, there is no clear evidence that firms requiring new financing want to signal their credibility through engaging an external auditor, and our results do not support the work of Carey et al. (2000). The accounts payable growth variable (APGROW) has an insignificant negative coefficient which is inconsistent with expectations. Overall, there is no evidence of a relationship between auditor choice and the degree of financial distress risk, with firms instead relying on a close relationship with banks and creditors (Ball and Shivakumar, 2005). We thus find no support for hypothesis H3. Importantly, excepting board independence, agency factors are not strong drivers of auditor choice. We suggest that the administrative auditing role of a BSA both mitigates type I and type II agency problems, and the conflict between the firms and the influential stakeholder.

With regard to the organizational complexity and risk factors, the size (SIZE) coefficient is positive and significant at the $1 \%$ level, consistent with expectations and with Knechel et al. (2008) and Aksu et al. (2007). This finding may be explained by the argument that agency costs increase with company size as the monitoring function is "inherently more difficult and expensive in a larger organization" (Jensen and Meckling, 1976, p. 59). Further, it is argued that there is more wealth at risk in larger companies, which increases agency costs (AbdelKhalik, 1993). Thus larger firms are more likely to appoint an external auditor, and hypothesis $H 4 a$ is supported. The coefficient for salaries to expenses (SALARY) is positive, which is inconsistent with expectations, though is insignificant. It is possible that it is too indirect a proxy for organizational complexity in Italian firms, particularly as salary expense ratios are similar across auditor choice firm types. However, we find that the second organizational complexity variable (COMPLEX) related to asset intensity is negative and significant at the $1 \%$ level, as expected, and thus increased 'asset complexity' leads to firms engaging a BSA rather than an external auditor. Our finding here may be explained in relation to the administrative role of a BSA whereby it monitors the firm's operations on a day-by-day basis, in turn taking the place of an external auditor in the control of firm complexity. Hypothesis $H 4 b$ is thus supported, though only for 'asset complexity' (COMPLEX) as increased firm complexity here reduces rather than increases the need for an external auditor. The coefficient of the subsidiary status variable (GROUP) is positive and significant at the 5\% level, and thus subsidiaries are more likely to assign their auditing to an external auditor, consistent with their parent, and in line with studies such as Knechel et al. (2008). Thus, hypothesis $H 4 c$ is supported.

With regard to 'risky' balance sheet components, the coefficient for inventory (INV) is 
positive and significant at the $5 \%$ level, which is inconsistent with our expectations, but consistent with the existing literature (Dedman et al., 2014; Simunic, 1980). This finding may be explained by non-listed firms with higher proportions of inventories wishing to obtain 'external' validation of these balances to stakeholders such as suppliers. However, the coefficient for receivables $(R E C)$ is negative and significant at the $10 \%$ level, as expected, contrasting with the results of Dedman et al. Thus, in contrast to inventories, this finding may be explained by the financial auditing role of the BSA as it remains a trusted professional and independent body with a financial auditing role, even where it constrains earnings management practices less than an external auditor. The coefficient for cash and cash equivalents $(\mathrm{CASH})$ is positive, consistent with Dedman et al. and inconsistent with our expectations, though is insignificant. The coefficient for revenue growth $(S A L E G R O W)$ is negative and insignificant, which is consistent with expectations, and inconsistent with Knechel et al. (2008) who find it to have a positive impact. Thus, perusal of our results across these four risky balance sheet components reveals that hypothesis $H 4 d$ is in general not supported, except in the case of receivables. Our findings here also provide evidence to support the role of a BSA within the corporate governance function of non-listed firms whereby it monitors firm complexity and risk. It may be that the administrative audit role of the BSA combined with the financial audit role, whereby it both monitors firm operations and monitors the preparation of its financial statements, validates these balances adequately, removing the need for an external auditor. The coefficient for firm age $(A G E)$ is negative as expected, consistent with Dedman et al., though is insignificant, and thus hypothesis $\mathrm{H} 4 \mathrm{e}$ is not supported. Thus, the length of establishment does not impact on auditor choice in our study.

In terms of the control variables, there is little evidence of profitability $(R O A)$ driving auditor choice, a result which is inconsistent with Dedman and Lennox (2007). The coefficient for legal form (LEGFORM) is positive, as expected, and significant at the $10 \%$ level, and thus there is weak evidence that firms incorporated as stock companies are more likely to engage an external auditor, consistent with the Italian Civil Code. The coefficient for IFRS is positive and significant at the $5 \%$ level, and thus as expected, external auditors are more likely to be engaged when a firm requires greater financial reporting expertise to deal with IFRS. The remaining control variables are insignificant and thus parent company nationality $(N A T)$ and industry type (IND) have no measurable impact on auditor choice.

\section{Conclusions}

This study examines the determinants of the choice between an external, high quality auditor and a BSA in Italian non-listed firms. As $52 \%$ of our sample firms are characterised by family ownership, we also investigate whether family ownership influences auditor choice in such firms. The existing literature argues that auditor choice may be driven by agency problems and/or the need for organizational effectiveness and efficiency, and is thus determined by organizational complexity and risk (Knechel et al., 2008; Dedman et al., 2014). In this paper, we argue that engaging a BSA as financial auditor potentially deals with organizational complexity in Italian non-listed firms as firms communicate privately with their stakeholders rather than having to engage highly qualified and expensive external auditors. We model auditor choice in relation to variables proxying for agency issues, organizational complexity, and firm risk factors.

In Italy, non-listed firms may assign financial auditing either to statutory auditors or to an external auditor. Independent statutory auditors (BSA) work within such firms on an operational basis and also conduct an administrative auditing function. Mariani et al. (2010) 
and Cameran and Prencipe (2011) argue that a BSA provides lower audit quality than an external auditor, while Bisogno (2012) finds no such evidence.

Our analysis shows that of the agency factors, only board independence, consistent with Beasley and Petroni (2001), drives auditor choice, with greater manager independence leading to the choice of an external auditor. According to Niskanen, Karjalainen, and Niskanen (2011), the demand for audit quality increases as managerial ownership decreases. However, consistent with both Niskanen et al., and with Darmadi (2012), we find no evidence of an impact of family ownership concentration on auditor choice, perhaps explained by the fact that $52 \%$ of the firms in our sample have high family ownership concentration. There is no evidence of an impact on auditor choice of the degree of internationalization, both in terms of foreign ownership and foreign sales. There is also no evidence of leverage or accounts payable growth impacting upon auditor choice. One interpretation here is that non-listed firms are more likely to communicate privately with shareholders, creditors, employees, suppliers, customers and other stakeholders than is the case for listed firms, thereby reducing the demand for high quality external auditors. Thus, our findings concerning leverage contrast with the findings of Carey et al. (2000), but are consistent with those of Fortin and Pittman (2007).

We also analyze the effect of organizational complexity proxies and audit risk on auditor choice. Our general hypothesis here is that increased audit complexity and risk issues are addressed in Italian non-listed firms by the BSA undertaking administrative auditing. This administrative function involves both the monitoring of the management and the firm's operations, thereby reducing the risk of firm failure or stakeholder fraud. As a result of the involvement of the BSA, it is argued that, in general, Italian firms have a reduced need for a high quality, external auditor to monitor firm organizational complexity and audit risk. One organizational complexity proxy is salary burden, though we find in our study that it has an insignificant impact. However, in our study we find that an increase in complexity in terms of asset intensity reduces the likelihood of choosing an external auditor, a finding inconsistent with Knechel et al. (2008). Our findings thus suggest that Italian non-listed firms tend to rely on the administrative auditing skills of a BSA i.e. the presence of a BSA mitigates both agency problems of non-listed firms and deals with organizational complexity and risk. It appears that non-listed firms need strong corporate governance monitoring by an independent and professional body such as a BSA more than they need financial auditing. Our findings provide some support for the EU Green paper on corporate governance and the OECD (2015) proposal which both aim to improve the corporate governance of European non-listed firms. However, we find that larger firms, and incorporated firms which are subsidiaries of larger entities, are more likely to choose an external auditor due to the expertise and independence which characterizes such auditors (Piot, 2005; Niskanen, Karjalainen, and Niskanen, 2011). We argue that larger firms are interested in signaling high quality accounting information, while incorporated firms are driven by a parent company in their choice of auditor. For larger incorporated firms, then, the engagement of an external auditor is not driven by operational control issues. Further, we find that firms with higher investment in inventories favor the choice of an external auditor, firms with higher receivables favor the choice of a BSA, while firm sales growth and length of establishment exert no discernable impact.

Finally, with regard to the control variables, we find that firms incorporated as stock companies and firms voluntarily adopting IFRS tend to choose an external auditor, though the effect is only weak in the case of the latter (as in Italy only about $1 \%$ of non-listed firms adopt IFRS voluntarily). We infer that engagement of an external auditor is a consequence of the adoption of IFRS. Firm profitability, industry membership and parent company nationality have no discernable impact on auditor choice. 
We argue that while Italian law mandates all non-listed stock companies and limited liability firms with equity over $€ 120,000$ to be audited, it is unlikely that such firms will in general feel compelled to appoint a high quality (external) auditor. Our findings suggest that such firms, which are typically small or medium-sized, are more likely to assign their financial auditing to a BSA, particularly when they are characterised by complexity. As firms engaging external auditors tend to pay far higher auditing fees as a result, this also tends to militate against non-listed companies selecting such an auditor (e.g. Ferguson et al., 2003; Choi et al., 2008; Francis and Wang, 2008). Ultimately, then, auditor choice becomes a tradeoff between the marginal benefits and marginal costs of appointing a more costly yet higher quality external auditor.

Our findings have three key implications for research and practice. The first implication is that non-listed firms do not necessarily enjoy all of the benefits discussed in the existing literature for listed companies when engaging a high quality external auditor. Indeed there may be a net 'economic' cost of so doing given the significant fees charged by external auditors, thereby working in the favour of the BSA in a competitive audit market. The second implication of our study is that non-listed firms derive more benefit from internal independent and professional control rather than they do from financial auditing as they attempt to mitigate agency conflicts. Our results suggest that the regulator might consider the introduction of a mandatory financial auditing threshold for smaller non-listed firms in recognition of this. Finally, European countries that are considering the introduction of the IPSB for the corporate governance of European SMEs might examine the benefits conferred by an independent, professional and internal administrative auditing body such as the BSA to help firms to manage both internal and external agency problems.

There are two limitations of our current study: (i) we selected the year 2009 alone as this was the most recent year available unaffected by auditing system and business law reform; and (ii) our sample data was necessarily constrained in size by the requirement for hand collected data, particularly that related to corporate governance factors.

\section{References}

Abbott, L.J. and Parker, S. (2000), "Auditor selection and audit committee characteristics", Auditing : A Journal of Practice and Theory (Fall), pp. 47-67.

Abdel-Khalik, A. (1993), "Why do private companies demand auditing? A case for organizational loss of control", Journal of Accounting, Auditing and Finance, Vol. 8 No. 1, pp. 31-52.

Aksu, M., Onder, T., and Saatcioglu, K. (2007), "Auditor selection, client firm characteristics, and corporate governance: evidence from an emerging markets", Working paper, Sabanci University, Istanbul, May. Available on the internet at http://www.academia.edu/1774882/Ownership_Concentration_Family_Control_and Auditor_Choice_Evidence_from_an_Emerging_Market (Accessed 24 October 2015).

AIDAF, Associazione Italiana Delle Aziende Familiari [Italian Association of Family Business - Family Business Network] (2015), "Le imprese familiari in Italia" [The Family Firms in Italy]. Available on the internet at http://www.aidaf.it/aidaf/leaziende-familiari-in-italia/ (Accessed 24 October 2015).

Ali, A., Chen, T.Y., and Radhakrishnan, S. (2007), "Corporate disclosures by family firms", Journal of Accounting and Economics, Vol. 44 No. 1-2, pp. 238-286.

An, Y. , (2015), "The Impact of Family Ownership on Firm Value and Earnings Quality: Evidence from Korea", International Business Management, Vol. 9, pp. 625-636.

Anderson, R.C., and Reeb, D.M. (2003), "Founding-family ownership and firm performance: evidence from the S\&P 500", The Journal of Finance, Vol. 61 No. 3, pp. 1301-1328. 
Ang, J., Cole, R. and Lin, J. (2000), "Agency costs and ownership structure”, Journal of Finance, Vol. 55 No. 1 pp. 81-106.

Ball, R. and Shivakumar, L. (2005), "Earnings quality in UK private firms: comparative loss recognition timeliness", Journal of Accounting and Economics, Vol. 3, pp. 83-128.

Beasley, M. (1996), "An empirical analysis of the relation between the board of director composition and financial statement fraud", The Accounting Review, Vol. 71, pp. 443465.

Beasley, M.S. and Petroni, K.R. (2001), "Board Independence and Audit Firm Type", Auditing: A Journal of Practice and Theory, Vol. 20 No. 1, pp. 96-114.

Beatty, A.L., Ke, B., and Petroni, K.R. (2002), "Earnings Management to Avoid Earnings Declines across Publicly and Privately Held Banks", The Accounting Review, Vol. 77 No. 3, pp. 547-570.

Becker, C.L., DeFond, M.L., Jiambalvo, J., and Subramanyam, K.R. (1998), "The effect of audit quality on earnings managementl, Contemporary Accounting Research, Vol. 15 No. 1, pp. 1-24.

Bharat, S.T., Sunder J. and Sunder, S.V. (2006), “Accounting Quality and Debt Contracting”, The Accounting Review, Vol. 83, pp. 1-28.

Bisogno, M. (2012), "Audit quality of Italian industrial non-listed firms: an empirical analysis", International Journal of Business Research and Development, Vol. 1 No. 1, pp. 32-47.

Blackwell, D. W., Noland, T.R.and Winters, D.B. (1998), "The value of auditor assurance: Evidence from loan pricing", Journal of Accounting Research, Vol 36 No. 1, pp. 5770.

Botosan, C. (1997), "Disclosure level and the cost of equity capital", Accounting Review, Vol. 72 No. 3, pp. 323-349.

Broye G. and Weill, L. (2008), "Does leverage influence auditor choice? A cross-country analysis", Applied Financial Economics, Vol. 18, pp. 715-731.

Bukart, M., Panunzi, F., Shleifer, A, (2003), "Family firms", The Journal of Finance, 53, pp. 2167-2199.

Bushman, R., Chen, Q., Engel, E., and Smith, A. (2004), "Financial accounting information, organizational complexity and corpo-rate governance systems", Journal of Accounting and Economics, Vol. 37, pp. 167-201.

Cameran, M. and Prencipe, A. (2011), "Qualità della revisione contabile e tipo di revisore. Il caso delle società italiane con quotate" [Audit quality and type of Auditor: An analysis on Italian non-listed companies], Economia \& Management, Vol. 1, pp. 99115.

Carey, P., Simnett, R. and Tanewski, G. (2000), "Voluntary Demand for Internal and External Auditing by Family Businesses", Auditing: A Journal of Practice and Theory, Vol. 19 (Supplement), pp. 37-51.

Cascino, S., Pugliese, A., Mussolino, D. and Sansone, C. (2010), "The influence of family ownership on the quality of accounting information", Family Business Review, Vol. 23 No. 3, pp. 246-265.

Chaney, P., Jeter, D. and Shivakumar, L. (2004), "Self-selection of auditors and audit pricing in private firms", The Accounting Review, Vol. 79 No. 1, pp. 51-72.

Chen, C., Yen, G., Fu, C. and Chang, F. (2007), "Family Control, Auditor Independence, and Audit Quality: Empirical Evidence from the TSE-Listed Firms (1999-2002)", Corporate Ownership and Control, Volume 4 Issue 3, pp.96-110.

Choi, J., Kim, J., Liu, X. and Simunic, D. (2008), "Audit Pricing, Legal Liability Regimes, and Big 4 Premiums: Theory and Cross-country Evidence", Contemporary Accounting Research, Vol. 25 No. 1, pp. 55-99. 
Copley, P.A. and Douthett, E.B. (2002), "The association between auditor choice, ownership retained, and earnings disclosure by firms making initial public offerings", Contemporary Accounting Research, Vol. 19 No. 1, pp. 49-75.

Darmadi, S. (2012), "Ownership Concentration, Family Control, and Auditor Choice: Evidence from an Emerging Market". Available at SSRN: http://ssrn.com/abstract=1999809 or http://dx.doi.org/10.2139/ssrn.1999809.

Dechow, P., Ge, W., and Schrand, C. (2010), "Understanding earnings quality: A review of the proxies, their determinants and their consequences", Journal of Accounting and Economics, Vol. 50, pp. 344--401.

Dechow, P., Sloan, R. and Sweeney, A. (1996), "Causes and consequences of earnings management: an analysis of firms subject to enforcement actions by SEC", Contemporary Accounting Research, Vol. 13 No 1, pp. 1-36.

Dedman, E. and Lennox, C. (2007), "Managers' perceptions of product market competition, profitability and firms' voluntary disclosures of sales", Working paper, Hong Kong University of Science and Technology. Available at : http://www.researchgate.net/publication/237718860 (Accessed 2 July 2015).

Dedman, E., Kausar, A., and Lennox C. (2014), "The Demand for Audit in Private Firms: Recent Large-Sample Evidence from the UK", European Accounting Review, Vol. 23 No. 1, pp. 1-23.

DeFond, M.L. (1992), "The Association Between Changes in Client Firm Agency Costs and Auditor Switching”, A Journal of Practice \& Theory, Vol. 11 No. 1, pp. 16-31.

Demirkan, S., Radhakrishnan, S., and Urcan, O. (2011) Discretionary accruals quality, cost of capital, and diversification, Journal of Accounting Auditing and Finance. forthcoming. doi:10.1177/ 0148558X11409162.

Dey, R.M., Hoi, C.K., and Robin, A. (2011), "Family Firms and Auditor Choice: A Focus on IPO Firms", Corporate Finance: Governance, Corporate Control \& Organization eJournal 09/2011, pp. 1-35.

Diamond, D. (1989), "Reputation acquisition in debt markets", Journal of Political Economy, Vol. 97 No. 4, pp. 828-862.

Dong, N. and Zhang, J.(2008), "Does Ownership Structure Matter When CPA Deciding Types of Audit .Opinions", Journal of Modern Accounting and Auditing, Vol.4 No.4, pp. 44-48.

EC, European Commission, (2013), "2013 SBA Fact Sheet, Italy", Available at http://ec.europa.eu/enterprise/policies/sme/facts-figures-analysis/performancereview/files/countries- sheets/2013/italy_en.pdf (Accessed on 4th December, 2014).

EC, European Commission (2011), "Green Paper: The EU Corporate Governance Framework". Available on the internet at http://eurlex.europa.eu/LexUriServ/LexUriServ.do?uri=COM:2011:0164:FIN:EN:PDF Accessed (20 February 2012).

Ecoda, The European Confederation of Directors Associations (2010), "Corporate Governance Guidance and Principles for Unlisted Companies in Europe". Available on the internet at http://ecoda.org/news-details/article/guidance-on-cg-for-unlistedcompanies-in-europe/ (Accessed 19 October 2015).

El Ghoul, S., Guedhami, O., Lennox, C.S., and Pittman, J. (2015), "External versus Internal Monitoring: The Importance of Multiple Large Shareholders and Families to Auditor Choice in Western European Firms". Available at SSRN: http://ssrn.com/abstract=1373808 or http://dx.doi.org/10.2139/ssrn.1373808.

El-Ghoul, S., Guedhami, O., Lennox, C., and Pittman, J.A. (2007), "Ownership Structure, Agency Problems, and Auditor Choice: Evidence from Western European Firms". 
Available at: http://www.apjfs.org/2007/report/311_guedhami2.pdf (Accessed 22 November 2015).

Fama, E. and Miller, M. (1972), The Theory of Finance, New York: Holt, Rhinehart and Winston.

Fama, E.F. (1980), "Agency Problems and the Theory of the Firm", Journal of Political Economy, Vol. 88, pp. 288-307.

Fama, E.F., and Jensen, M.C. (1983), "Separation of Ownership and Control", Journal of Law and Economics, Vol. 26, pp. 301-325.

Fan, J.P.H., and Wong, T.J. (2005), "Do external auditors perform a corporate governance role in emerging markets? Evidence from East Asia", Journal of Accounting Research, Vol. 43 No. 1, pp. 35-72.

Favero CA, Giglio SW, Honorati M, and Panunzi F. (2006), "The Performance of Italian Family Firms", ECGI Working Paper No. 127/2006. Available on the internet at http://ssrn.com/abstract_id=918181 (Accessed 22 October 2015).

Ferguson, A., Francis, J. and Stokes, D. (2003), "The effects of firm-wide and office-level industry expertise on audit pricing", The Accounting Review (April), pp. 429-448.

Fortin, S. and Pittman, J. (2007), "The role of auditor choice in debt pricing in private firms", Contemporary Accounting Research, Vol. 24 No. 3, pp. 859-896.

Francis, J.R., Richard, C., and Vanstraelen, A. (2009), "Assessing France's joint audit requirement: are two heads better than one?", Auditing: A Journal of Practice and Theory, Vol. 28 No. 2, pp. 35-63.

Francis, J. and Wang, D. (2008), "The Joint Effect of Investor Protection and Big 4 Audits on Earnings Quality around the World", Contemporary Accounting Research, Vol. 25 No. 1, pp. 157-191.

Francis, J., Maydew, E. and Sparks, H. (1999), "The role of Big Six auditors in the credible reporting of accruals", Auditing: A Journal of Practice and Theory, Vol. 18 No. 2, pp. pp. 17-34.

Ge, W. and McVay, S. (2005), "The disclosure of material weaknesses in internal control after the Sarbanes-Oxley Act", Accounting Horizons, 19 September, pp. 137-158.

Godwin, M. and Freedman, J. (1993), "The statutory audit and the micro company - an empirical investigation", Journal of Business Law, March, pp. 103-130

Gul, F.A. and Tsui, J.S.L. (2001), "Free cash flow, debt monitoring, and audit pricing: Further evidence on the role of director equity ownership", Auditing: A Journal of Practice and Theory, Vol. 20 No. 2, pp. 71-84.

Hail, L., Leuz, C., and Wysocki, P. (2010), "Global accounting convergence and the potential adoption of IFRS by the U.S. (Part I): Conceptual underpinnings and economic analysis", Accounting Horizons, Vol. 24 No. 3, pp. 355-394.

Hay, D., Knechel, W. R. and Wong, N. (2006), "Audit fees: A meta-analysis of the effect of supply and demand attributes", Contemporary Accounting Research, Vol. 23, Spring, pp. 141-192.

Hay, D. and Davis, D. (2004), "The voluntary choice of an auditor of any level of quality", Auditing: A Journal of Practice and Theory, Vol. 23 No. 2, pp. 37-53.

$\mathrm{Hu}, \mathrm{Y}$. and Izumida, S. (2008), "Ownership Concentration and Corporate Performance: A Causal Analysis .with Japanese Panel Data", Corporate Governance: An International Review, Vol. 16 No. 4, pp. 342-358.

Jaggi, B., Leung S. and Gul, F. (2009), "Family Control, Board Independence and Earnings Management: evidence Based on Hong Kong Firms", Journal of Accounting and Public Policy, Vol. 28 No. 4, pp. 281-300. 
Jensen, M. and Meckling, W. (1976), "Theory of firm: Managerial behavior, agency costs and ownership structure", Journal of Financial Economics, Vol. 3(October), pp. 305360.

Karim, A., Van Zijl, T. and Mollah, S. (2013), "Impact of board ownership, CEO-Chair duality and foreign equity participation on auditor quality choice of IPO companies: evidence from an emerging market", International Journal of Accounting and Information Management, Vol. 21 No. 2, pp.148-169.

Kinney, J. and McDaniel, L. (1989), "Characteristics of firms correcting previously reported quarterly earnings", Journal of Accounting and Economics, Vol. 11 No. 1, pp. 71-93.

Knechel, R., Niemi, L. and Sundgren, S. (2008), "Determinants of Auditor Choice: Evidence from a Small Client Market", International Journal of Auditing, Vol. 12, pp. 65-88.

Knechel, W. (2002), "The role of the independent accountant in effective risk management", Tijdschrift voor Economie en Management, Vol. 11, pp. 65-86.

Krishnan, G.V. (2003), "Does Big-6 auditor industry expertise constrain earnings management?", Accounting Horizons, Vol. 17, pp. 1-16.

Iacovone, D. (2015), "Imprese e familiari in crescita nel mondo" [Family businesses growing in the world], in Il Sole 24 Ore, 5 Febbraio.

ICG (2011), Institute for Corporate Governance, Contribution to Public Consultation on Green Paper, The EU Corporate governance Framework COM (2011) 164 Final, available

at

https://www.google.com/url?sa $=$ t\&rct $=\mathrm{j} \& \mathrm{q}=\&$ esrc $=$ s\&source $=$ web\&cd $=1 \& v e d=0 \mathrm{CB}$ 8QFjAAahUKEwjgjOqPwbHIAhWCzxoKHYo_A9w\&url=http\%3A\%2F\%2Fec.euro pa.eu\%2Finternal_market\%2Fconsultations\%2F2011\%2Fcorporate-governance-

framework $\% 2$ Fregistered-organisations $\% 2$ Fistituto-per-il-governo-

societario_en.pdf\&usg=AFQjCNFY9Kok0JLAQr6mKLjqI9kA6_urzA\&sig2=1gCD

QC1WxwlqzRPNCX9MAA (Accessed 17 June 2015).

Italian Stock Exchange, (2014), Review dei mercati 2014 [2014 Market Review], Available on the internet at http://www.borsaitaliana.it/borsaitaliana/ufficio-stampa/comunicatistampa/2014/review2014.htm (Accessed 7 May 2015).

La Rocca, M. and Montalto, F. (2012), "Ownership concentration and corporate performance: the Italian case". Available on the internet at https://www.google.com/url?sa $=$ t\&rct $=\mathrm{j} \& \mathrm{q}=\&$ esrc $=$ s\&source $=$ web \& $\mathrm{cd}=8 \& \mathrm{ved}=0 \mathrm{CE}$ wQFjAHahUKEwi-

n7C19NXIAhVBXRQKHepTARY\&url=http\%3A\%2F\%2Fwww.mfsociety.org\%2F modules\%2FmodDashboard\%2FuploadFiles\%2Fconferences\%2FMC19 504 p16p5 v1bf117u0b091ifu16242mn4.pdf\&usg=AFQjCNE6FCLMWfMFu545Qui4ROaGpR KJhw\&sig2=ouDtRAYQA48Q-xVfFaKfpA\&cad=rja (Accessed 18 July 2015).

Lee, P., Stokes, D., Taylor, S., and Walter, T. (2003), "The Association Between Audit Quality, Accounting Disclosures and Firm-Specific Risk: Evidence from Initial Public Offerings", Journal of Accounting and Public Policy, Vol. 22, No. 5, pp. 377-406.

Lennox, C. (2005), "Management Ownership and Audit Firm Size", Contemporary Accounting Research, Vol. 22 No. 1, pp. 205-227.

Lin, Z. and Liu, M. (2009), "The impact of corporate governance on auditor choice: evidence from China", Journal of International Accounting, Auditing and Taxation, Vol. 18, pp. 44-59.

Liu, C.L., and Lai, S.M. (2012), "Organizational Complexity and Auditor Quality", Corporate Governance: An International Review, Vol. 20 No. 4, pp. 352-368.

Mahdavi, G., Monfared Maharlouie, M., Ebrahimi, F. and Sarikhani, M. (2011), "The Impact of Corporate Governance on Auditor Choice", International Research Journal of Finance and Economics, Vol. 68, pp. 129-139. 
Mansi, S., Maxwell, W. and Miller, D. (2004), "Does auditor quality and tenure matter to investors? evidence from the bond market", Journal of Accounting Research, Vol. 42 No. 4, pp. 755-794.

Mariani, L., Tettamanzi, P. and Corno, F. (2010), "External Auditing vs Statutory Committee Auditing: the Italian Evidence", International Journal of Auditing, Vol. 14 pp. 25-40.

Melis, A. (2004), "On the Role of the Board of Statutory Auditors in Italian Listed Companies", Corporate Governance, Vol. 12 No. 1, pp. 74-84.

Mengoli, S., Pazzaglia, F., and Sapienza, E. (2009), "Effect of governance reforms on corporate ownership in Italy: Is it still pizza, spaghetti and mandolino?", Corporate Governance: An International Review, Vol. 17 No. 5, pp. 629-645.

Morck, R., and Yeung, B. (2004), "Family control and the rent-seeking society", Entrepreneurship Theory and Practice, Vol. 28 No. 4, pp. 391-409.

Nagar, V., Petroni, K., and Wolfenzon, D. (2011), "Governance problems in closely held corporations", Journal of Financial and Quantitative Analysis, Vol. 46 No. 4, pp. 943-966.

Newton, J. and Ashton, R. (1989), "The association between audit report technology and audit delay", Auditing: A Journal of Practice and Theory, Vol. 8 (Suppl.), pp. 22-37.

Niskanen, M., Karjalainen, J. and Niskanen, J. (2011), "Demand for Audit Quality in Private Firms: Evidence on Ownership Effects", International Journal of Auditing, Vol. 15, pp. 43-65.

Niskanen, M., Karjalainen, J., and Steijvers, T. (2011), "Audit Quality: The Role of Board Structure in Family Firms". Available at SSRN: http://ssrn.com/abstract=1937511 or http://dx.doi.org/10.2139/ssrn.1937511.

Niskanen, M., Karjalainen, J., and Niskanen, J. (2010), "The role of auditing in small private family firms: is it about quality and credibility?", Family Business Review, Vol. 23 No. 3, pp. 230-245.

OEC, Ordes Des Experte Comptables (France), National Conseil of Italian Chartered Accountants (Italy), and Economistas - Consejo General (2010), "Independent Professional Supervisory Board". Available on the internet at http://economistas.org/gestor/personal/upload/noticias/DOC\%20TRILATERAL\%201 00410\%20ENG\%20ESP\%20FRA\%20ITA.pdf. Accessed (3 September 2015).

OECD (2015), "Principles of Corporate Governance", available on the internet at http://www.oecd.org/corporate/principles-corporate-governance.htm (Accessed 19 October 2015).

OECD (2004), "Principles of Corporate Governance", available on the internet at https://www.google.com/url?sa $=$ t\&rct $=\mathrm{j} \& \mathrm{q}=\&$ esrc $=$ s\&source=web\&cd $=1 \& v e d=0 \mathrm{CCI}$ QFjAAahUKEwj3laak9M7IAhVIvhQKHW9hB2Q\&url=http\%3A\%2F\%2Fwww.oec d.org $\% 2$ Fcorporate $\% 2 \mathrm{Fca} \% 2 \mathrm{Fcorporategovernanceprinciples} \% 2 \mathrm{~F} 31557724$.pdf\&usg $=$ AFQjCNF9GEZCyJUoFWOYQf-Sdv

Wmx1PYg\&sig2=1sATbDjOKhuDvGxR41n76Q (Accessed 19 October 2015).

Osservatorio AUB (2014), " $6{ }^{\circ}$ Osservatorio AUB sulle aziende familiari italiane" [The 6th AUB Observatory on Italian family firms]" Bocconi University. Available at http://www.aidaf.it/wp-content/uploads/2014/08/Osservatorio-AUB-6edizionepdf.pdf (Accessed 17 March 2015)

Peasnell, K., Pope P. and Young, S. (2000), “Accrual management to meet earnings targets: UK evidence preand post-Cadbury", The British Accounting Review, Vol. 32 No. 4, pp. 415-445.

Peek, E., Cuijpers, R. and Buijink, W. (2010), “Creditors' and Shareholders' Reporting Demands in Public Versus Private Firms: evidence from Europe", Contemporary Accounting Research, Vol. 27 No. 1, pp. 49-91. 
Piot, C. (2005), "Auditor Reputation and Model of Governance: a Comparison of France, Germany and Canada", International Journal of Auditing, Vol. 9, pp. 21-44.

Pittman, J. A., and Fortin, S. (2004), Auditor choice and the cost of debt capital for newly public firms, Journal of Accounting and Economics, 37 No. 1, pp. 113-136.

Rajan, R. and Zingales, L. (1998), "Financial dependence and growth", American Economic Review, Vol. 88 No. 3, pp. 559-586.

Rogers, J.L., and Stocken, P.C. (2005), "Credibility of Management Forecasts", The Accounting Review, Vol. 80 No. 4, pp. 1233-1260.

Simunic, D. (1980), "The pricing of audit services: theory and evidence", Journal of Accounting Research, Vol. 18 No. 1, pp. 161-190.

Simunic, D. and Stein, M. (1987), "Product Differentiation in Auditing: Auditor Choice in the Market for Unseasoned New Issues", The Canadian Certified General Accountants' Research Foundation Vancouver, BC.

Steijvers, T., Voordeckers, W., and Vanhoof, K. (2010), "Collateral, relationship lending and family firms", Small Business Economics, Vol. 34 No. 3, pp. 243-259.

Stice, J. (1991), "Using financial and market information to identify pre-engagement factors associated with lawsuits against auditors", The Accounting Review, Vol 66 No. 3, pp. $516-534$.

Van Tendeloo, B., and Vanstraelen, A. (2008), "Earnings management and audit quality in Europe: evidence from the private client segment market", The European Accounting Review, Vol. 17 No. 3, pp. 447-469.

Van Zijl, T. and Karim, A. (2010), "Clients' Corporate Governance Characteristics and Auditor Choice in Emerging Audit Services Markets: The Case of Bangladesh" Available on the internet at http://ssrn.com/abstract=1613453 (Accessed 30 April 2012).

Villalonga, B., and Amit, R. (2006), "How do family ownership, control, and management affect firm value?", Journal of Financial Economics, Vol. 80, pp. 385-417.

Vinciguerra R., and Cipullo N. (2009), "The economic and financial communications for SMEs from the point of view of accounting professionals: an empirical investigation", Financial Reporting, Vol. 1, pp. 39-78.

Wallace, W. (1987), "The economic role of the audit in free and regulated markets: A review", Research in Accounting Regulation, Vol. 1, pp. 1-34.

Wang D. (2006), "Founding family ownership and earnings quality", Journal of Accounting Research, Vol. 44, pp. 619-656.

Watts, R. and Zimmerman, J. (1986), Positive Accounting Theory, NewYork: Prenctice-Hall.

Xie, B., Davidson, W. and DaDalt, P. (2003), "Earnings management and corporate governance: the roles of the board and the audit committee", Journal of Corporate Finance, Vol. 9, pp. 295-316.

Zanardi S. (2010), "Il Collegio sindacale a caccia di maggiori spazi in Europa" [The Board of Statutory Auditors on the hunt for more space in Europe], Il Sole 24 Ore, 16 April 2010, p. 35.

Zarzeski, M. (1996), "Spontaneous harmonization effects of culture and market forces on accounting disclosure practises", Accounting Horizons, Vol. 10 No. 1, pp. 18-37. 
Table 1. Auditing bodies and the Italian "traditional" corporate governance model

\begin{tabular}{|c|c|c|c|}
\hline Model & Type of company/legal form & Administrative audit & Financial audit \\
\hline Traditional & $\begin{array}{l}\text { Listed } \\
\text { Non-listed Type } 1 * / \mathrm{PC} \text { and LlC } \\
\text { Non-listed Type } 2 * * / \mathrm{PC} \\
\text { Non-listed Type } 2 * * / \mathrm{Llc}\end{array}$ & $\begin{array}{c}\text { Board of Statutory } \\
\text { Auditors (BSA) }\end{array}$ & $\begin{array}{l}\text { Auditing company (AC) } \\
\text { Single auditor (SA) or AC } \\
\text { 1) SA or AC, or 2) BSA } \mathrm{BS}^{\mathrm{a}} \text { (art. 2409-bis) } \\
\text { 1) BSA or 2) SA or } \mathrm{AC}^{\text {a }} \text { (art. 2477) } \\
\end{array}$ \\
\hline \multicolumn{4}{|c|}{$\begin{array}{l}\text { a If allowed by a company's by-laws } \\
\text { * Type 1: firms of public interest which are obliged to prepare consolidated financial statements } \\
\text { ** Type 2: firms that do not have public accountability, and are not obliged to prepare consolidated financial statements } \\
\text { PC = stock or public company; Llc = limited liabilitity company }\end{array}$} \\
\hline
\end{tabular}


Table 2. The sample size and auditing system adopted by Italian non-listed firms

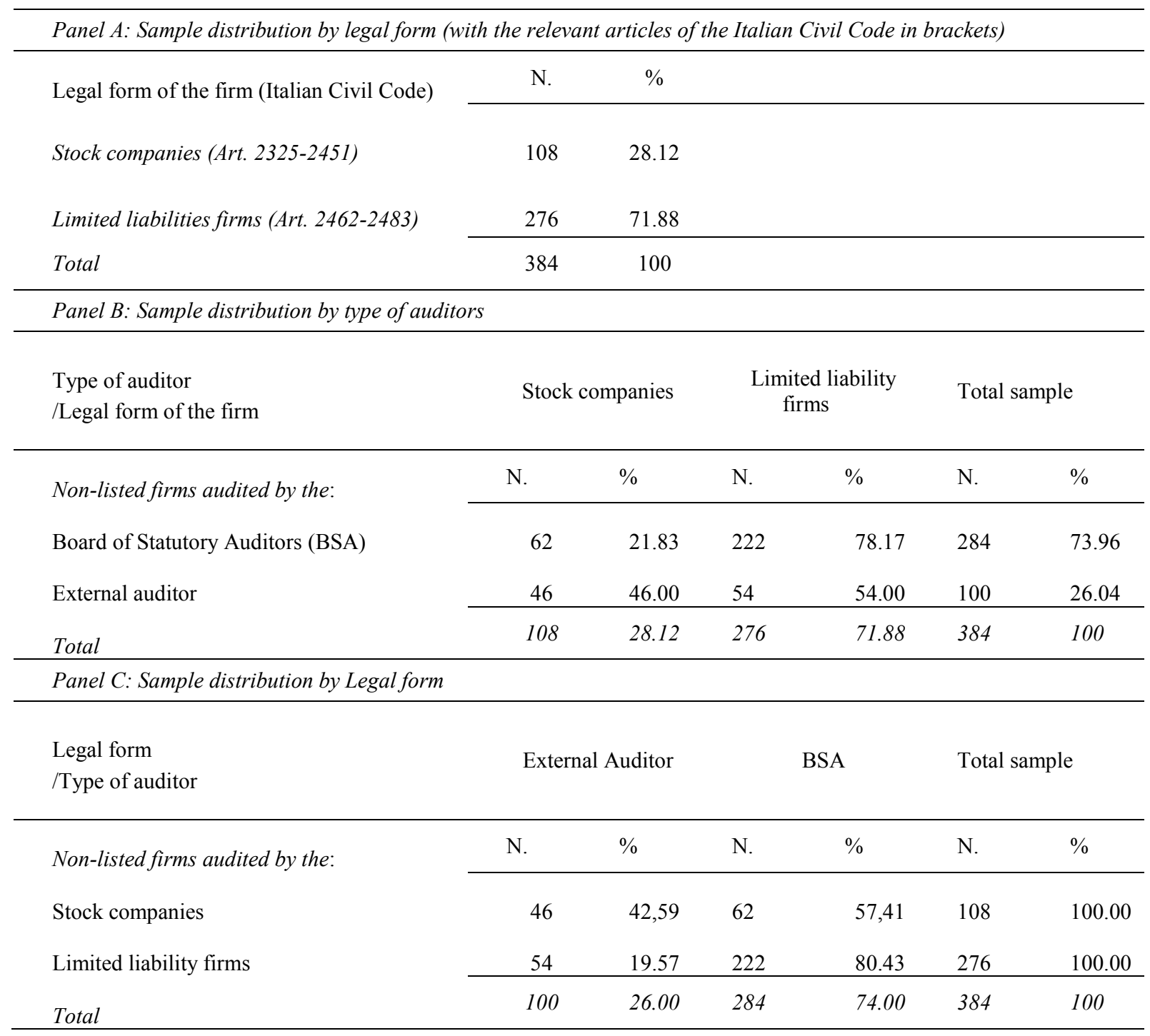


Table 3. Variable measurement

\begin{tabular}{|c|c|c|c|}
\hline $\begin{array}{c}\text { Independent } \\
\text { variable }\end{array}$ & Variable description & $\begin{array}{l}\text { Expected } \\
\text { sign }\end{array}$ & Hypothesis \\
\hline$O W N$ & $\begin{array}{l}\text { Family ownership concentration, proxied by family control and closely held } \\
\text { ownership ( } 1=\text { at least } 50 \% \text { of voting rights or outstanding shares held by a } \\
\text { family block holder; } 0=\text { otherwise). }\end{array}$ & - & H1a \\
\hline FOWN & $\begin{array}{l}\text { Degree of foreign ownership }(1=\text { firm has at least one foreign shareholder; } 0= \\
\text { otherwise }) \text {. }\end{array}$ & + & $\mathrm{H} 1 \mathrm{~b}$ \\
\hline$B O A R D$ & $\begin{array}{l}\text { Degree of manager independence, i.e. proportion of independent managers on the } \\
\text { Board }(1=\text { at least } 50 \% \text { of managers are independent; } 0=\text { otherwise). }\end{array}$ & $+/-$ & $\mathrm{H} 1 \mathrm{c}$ \\
\hline FSALES & $\begin{array}{l}\text { Foreign revenues, i.e. proportion of sales which are international (outside sales } \\
\text { divided by total sales). }\end{array}$ & + & $\mathrm{H} 2$ \\
\hline$L E V$ & $\begin{array}{l}\text { Leverage ratio, i.e. debt to banks, other capital providers, and bondholders scaled } \\
\text { by total assets. }\end{array}$ & + & H3 \\
\hline$A P G R O W$ & Trade credit or accounts payable, i.e. total accounts payable scaled by total assets. & + & $\mathrm{H} 3$ \\
\hline SIZE & Measure of asset and operational complexity, i.e. natural logarithm of total assets. & + & $\mathrm{H} 4 \mathrm{a}$ \\
\hline SALARY & Salaries, i.e. salaries paid scaled by total operating expenses. & - & $\mathrm{H} 4 \mathrm{~b}$ \\
\hline COMPLEX & $\begin{array}{l}\text { Firm organizational complexity, i.e. sum of tangible, intangible, financial assets, } \\
\text { and inventories scaled by total assets. }\end{array}$ & - & $\mathrm{H} 4 \mathrm{~b}$ \\
\hline GROUP & Subsidiary status dummy ( $1=$ firm is a subsidiary; $0=$ otherwise $)$ & + & $\mathrm{H} 4 \mathrm{c}$ \\
\hline$I N V$ & Inventories, i.e. inventories scaled by total assets. & - & $\mathrm{H} 4 \mathrm{~d}$ \\
\hline$R E C$ & Receivables, i.e. stock of receivables scaled by total assets. & - & $\mathrm{H} 4 \mathrm{~d}$ \\
\hline $\mathrm{CASH}$ & $\begin{array}{l}\text { Cash and cash equivalents, i.e. stock of cash and cash equivalents scaled by total } \\
\text { assets. }\end{array}$ & - & $\mathrm{H} 4 \mathrm{~d}$ \\
\hline SALEGROW & Revenue growth rate, i.e. relative change in revenues. & - & $\mathrm{H} 4 \mathrm{~d}$ \\
\hline$A G E$ & Firm age, i.e. natural log of firm years of establishment. & - & $\mathrm{H} 4 \mathrm{e}$ \\
\hline$R O A$ & Firm profitability, i.e. return on assets. & - & - \\
\hline LEGFORM & $\begin{array}{l}\text { Legal form, i.e. incorporation status dummy }(1=\text { firm incorporated as stock } \\
\text { company; } 0=\text { otherwise }) \text {. }\end{array}$ & + & - \\
\hline IFRS & $\begin{array}{l}\text { Voluntary adoption of full IAS/IFRS in financial statements, i.e. dummy }(1=\text { firm } \\
\text { complies with IAS/IFRS; } 0=\text { otherwise }) \text {. }\end{array}$ & + & - \\
\hline$N A T$ & Parent company nationality dummy ( 1 = foreign parent company; $0=$ otherwise $)$ & + & - \\
\hline$I N D$ & Industry dummy ( $1=$ SIC code $2 / 3$ manufacturer; $0=$ otherwise $)$ & $\mathrm{n} / \mathrm{a}$ & - \\
\hline
\end{tabular}


Table 4. Dummy variable descriptive by auditor type

\begin{tabular}{|c|c|c|c|c|c|c|c|c|}
\hline & \multicolumn{8}{|c|}{ Dichotomous variables (sample $\mathrm{N}=384$ ) } \\
\hline & \multicolumn{4}{|c|}{$\begin{array}{l}\text { Panel A: } \\
\text { Audited by a BSA }(N=284)\end{array}$} & \multicolumn{4}{|c|}{$\begin{array}{l}\text { PANEL B: } \\
\text { Audited by an external auditor }(N=100)\end{array}$} \\
\hline & \multicolumn{2}{|c|}{0} & \multicolumn{2}{|l|}{1} & \multicolumn{2}{|c|}{0} & \multicolumn{2}{|c|}{1} \\
\hline Variable & Frequency & $\%$ & Frequency & $\%$ & Frequency & $\%$ & Frequency & $\%$ \\
\hline$O W N$ & 103 & 36.3 & 181 & 63.7 & 82 & 82.0 & 18 & 18.0 \\
\hline FOWN & 255 & 89.8 & 29 & 10.2 & 55 & 55.0 & 45 & 45.0 \\
\hline$B O A R D$ & 187 & 65.8 & 97 & 34.2 & 18 & 18.0 & 82 & 82.0 \\
\hline GROUP & 193 & 68.0 & 91 & 32.0 & 22 & 22.0 & 78 & 78.0 \\
\hline LEGFORM & 222 & 78.2 & 62 & 21.8 & 54 & 54.0 & 46 & 46.0 \\
\hline$I N D$ & 98 & 34.5 & 186 & 65.5 & 34 & 34.0 & 66 & 66.0 \\
\hline$N A T$ & 255 & 89.8 & 29 & 10.2 & 58 & 58 & 42 & 42 \\
\hline IFRS & 283 & 99.6 & 1 & 0.4 & 95 & 95 & 5 & 5 \\
\hline
\end{tabular}

Table 5. Continuous variable descriptive statistics

\begin{tabular}{lcccccc|lcccccc}
\hline Panel A: Firms engaging $a$ BSA & $(N=284)$ & & & & \multicolumn{7}{l}{ Panel B: Firms engaging an external auditor $(N=100)$} \\
\hline Variable & Mean & S.E. & Median & S.D. & Min. & Max. & Variable & Mean & S.E. & Median & S.D. & Min. & Max. \\
\hline FSALES & 0.106 & 0.013 & 0.000 & 0.219 & 0.00 & 1.00 & FSALES & 0.101 & 0.023 & 0.000 & 0.226 & 0.00 & 1.00 \\
LEV & 0.139 & 0.011 & 0.025 & 0.183 & 0.00 & 0.68 & LEV & 0.176 & 0.020 & 0.090 & 0.199 & 0.00 & 0.73 \\
APGROW & 0.074 & 0.042 & -0.040 & 0.708 & -0.77 & 8.43 & APGROW & -0.011 & 0.038 & -0.020 & 0.385 & -0.87 & 1.31 \\
SALARY & 0.172 & 0.008 & 0.140 & 0.128 & 0.00 & 0.83 & SALARY & 0.179 & 0.012 & 0.160 & 0.122 & 0.00 & 0.57 \\
COMPLEX & 0.497 & 0.014 & 0.500 & 0.231 & 0.00 & 0.99 & COMPLEX & 0.414 & 0.024 & 0.430 & 0.243 & 0.01 & 0.96 \\
SIZE & 9.678 & 0.055 & 9.580 & 0.930 & 7.13 & 12.54 & SIZE & 10.47 & 0.138 & 10.255 & 1.382 & 7.81 & 13.98 \\
INV & 0.350 & 0.058 & 0.103 & 0.986 & 0.00 & 9.39 & INV & 0.059 & 0.202 & 0.156 & 2.020 & 0.00 & 14.01 \\
REC & 0.678 & 0.080 & 0.358 & 1.346 & 0.000 & 14.20 & REC & 0.621 & 0.128 & 0.308 & 1.280 & 0.00 & 10.84 \\
CASH & 0.062 & 0.006 & 0.017 & 0.098 & -0.02 & 0.61 & CASH & 0.062 & 0.009 & 0.026 & 0.919 & 0.00 & 0.64 \\
AGE & 3.086 & 0.045 & 3.220 & 0.762 & 0.69 & 4.64 & AGE & 3.015 & 0.091 & 3.178 & 0.910 & 0.69 & 4.64 \\
SALEGROW & 0.044 & 0.011 & 0.100 & 0.192 & -0.63 & 2.41 & SALEGROW & 0.023 & 0.146 & 0.010 & 0.146 & -0.71 & 0.63 \\
ROA & 2.973 & 0.435 & 2.610 & 7.336 & -44.34 & 43.61 & ROA & 3.815 & 1.009 & 2.710 & 10.087 & -23.55 & 34.11 \\
\hline
\end{tabular}


Table 6. Correlation matrix for the model variables

\begin{tabular}{|c|c|c|c|c|c|c|c|c|c|c|c|c|c|c|c|c|c|c|c|c|c|}
\hline & AUDIT & OWN & FOWN & $B O A R D$ & FSALES & $L E V$ & APGROW & $\begin{array}{l}\text { SALE } \\
\text { GROW }\end{array}$ & SALARY & COMPLEX & SIZE & GROUP & $I N V$ & $R E C$ & CASH & $A G E$ & IFRS & NAT & $R O A$ & $\begin{array}{c}\text { LEG } \\
\text { FORM }\end{array}$ & $I N D$ \\
\hline$A U D I T$ & 1.000 & -.402 & $.387^{* 1 *}$ & $.421^{* \prime \prime}$ & .001 & .086 & .004 & $\begin{array}{l}.012 \\
814\end{array}$ & .034 & -.147 & $.260 "$ & .406 & .059 & $\begin{array}{l}-.039 \\
.050\end{array}$ & .089 & -.036 & .164 & $.3599^{\prime \prime}$ & .033 & $.236^{\prime \prime \prime}$ & .005 \\
\hline$O W N$ & $-.402^{*}$ & $\begin{array}{c}.000 \\
1\end{array}$ & & $\begin{array}{c}.000 \\
-.760^{* * *}\end{array}$ & .984 & $.091 *$ & .945 & .814 & .510 & .004 & .000 & .000 & .249 & .450 & .081 & .481 & .001 & .000 & .514 & 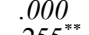 & .927 \\
\hline$O W N$ &.- .4000 & 1 & $\begin{array}{l}-.427 \\
-000\end{array}$ & $\begin{array}{l}-.760 \\
000\end{array}$ & .086 & $\begin{array}{l}-.109 \\
032\end{array}$ & -.022 & .060 & -.024 & $.115^{\circ}$ & $-.261^{* \prime \prime}$ & $-.615^{\prime \prime}$ & -.038 & -.014 & .005 & .022 & -.089 & $-.319^{*}$ & .048 & $-.255^{\circ}$ & -.028 \\
\hline FOWN & $.387^{* *}$ & $-.427^{* *}$ & .000 & $.004^{* * \pi}$ & .058 & .032 & .668 & .240 & .633 & $\begin{array}{l}.024 \\
153^{* * *}\end{array}$ & .000 & .000 & .455 & .783 & .916 & .671 & .083 & .000 & .346 & .000 & .578 \\
\hline & .000 & .000 & & .000 & .253 & .365 & .121 & .584 & .814 & $\begin{array}{l}-.153 \\
.003\end{array}$ & .001 & .498 & .056 & $\begin{array}{l}-.080 \\
.118\end{array}$ & $\begin{array}{l}.001 \\
.983\end{array}$ & $\begin{array}{l}-.018 \\
.732\end{array}$ & .003 & .000 & -.017 & .150 & $\begin{array}{r}-.036 \\
.486\end{array}$ \\
\hline$B O A R D$ & $.421^{* *}$ & $-.760^{* *}$ & $.404^{* *}$ & 1 & -.018 & .021 & .007 & -.074 & -.011 & -.082 & $.272^{* *}$ & $.528^{* *}$ & .033 & -.040 & .013 & -.007 & .093 & $.348^{* *}$ & -.054 & $.263^{* *}$ & .006 \\
\hline & .000 & .000 & .000 & & .727 & .685 & .896 & .149 & .824 & .108 & .000 & .000 & .524 & .433 & .798 & .884 & .069 & .000 & .290 & .000 & .909 \\
\hline FSALES & -.010 & $.108^{*}$ & .029 & -.048 & 1 & .009 & -.033 & .037 & .039 & $.103^{*}$ & $.104^{*}$ & -.027 & .047 & .016 & .002 & -.057 & .024 & .027 & .047 & $.118^{*}$ & .014 \\
\hline & .847 & $.034 *$ & .573 & .347 & & .859 & .518 & .470 & .448 & .044 & .041 & .602 & .354 & .756 & .972 & .265 & .645 & .593 & .359 & .021 & .789 \\
\hline$L E V$ & .086 & $-.102^{*}$ & .047 & .024 & -.022 & 1 & -.054 & -.030 & .052 & .078 & -.006 & $.120^{\circ}$ & .048 & -.093 & $-.175^{* *}$ & -.053 & .053 & -.015 & -.092 & .064 & -.030 \\
\hline$A P G R O W$ & .094 & .045 & .361 & .633 & .672 & & .289 & .555 & .314 & .129 & .905 & .019 & .345 & .069 & .001 & .297 & .29 & .775 & .071 & .210 & .564 \\
\hline AT UNOH & $\begin{array}{r}-.058 \\
253\end{array}$ & $\begin{array}{l}-.035 \\
497\end{array}$ & -.063 & -.022 & -.055 & $\begin{array}{l}-.046 \\
360\end{array}$ & 1 & .056 & .023 & .042 & .130 & .014 & -.041 & -.017 & -.085 & .027 & -.129 & -.073 & .026 & .015 & -.037 \\
\hline SALEGROW & -.051 & -.007 & .026 & $\begin{array}{l}-.074 \\
-.048\end{array}$ & $\begin{array}{l}-.038 \\
-.038\end{array}$ & $\begin{array}{l}.309 \\
-.033\end{array}$ & $.122^{*}$ & .270 & $\begin{array}{l}.041^{*} \\
121^{*}\end{array}$ & $\begin{array}{r}.414 \\
002\end{array}$ & $\begin{array}{l}.011 \\
-.082\end{array}$ & -.054 & $\begin{array}{l}.424 \\
055\end{array}$ & $\begin{array}{r}.74 \\
013\end{array}$ & .042 & $\begin{array}{l}.594 \\
064\end{array}$ & $\begin{array}{l}.012 \\
.004\end{array}$ & $\begin{array}{l}.153 \\
-.012\end{array}$ & $\begin{array}{l}.614 \\
-.075\end{array}$ & .764 & .474 \\
\hline & .319 & .892 & .614 & .349 & .457 & .523 & .017 & & .018 & .967 & .107 & .287 & .284 & .801 & .414 & .213 & .938 & .816 & .144 & .060 & .461 \\
\hline SALARY & .025 & -.017 & .004 & -.032 & .021 & .021 & -.022 & .049 & 1 & $.197^{* *}$ & -.084 & .044 & -.011 & -.056 & .038 & .013 & .008 & .008 & -.068 & -.037 & .095 \\
\hline & .626 & $.738 *$ & .940 & .527 & $.683 x$ & .685 & .667 & .339 & & .000 & $.100_{* x}$ & .390 & .826 & .276 & .455 & .799 & .869 & .875 & .186 & .464 & .063 \\
\hline COMPLEX & $-.154^{* *}$ & $.123^{*}$ & $-.152^{* *}$ & -.092 & $.102^{*}$ & .087 & -.045 & .033 & $.121^{*}$ & 1 & $.199^{* *}$ & $-.116^{*}$ & .050 & -.085 & .016 & .017 & -.058 & -.093 & $-.205^{* *}$ & -.066 & $.202^{* *}$ \\
\hline & .003 & .016 & .003 & .072 & .047 & .090 & .383 & .522 & .018 & & .000 & .023 & .326 & .097 & .756 & .740 & .259 & .068 & .000 & .195 & .000 \\
\hline SIZE & $.309^{* *}$ & $-.260^{* *}$ & $.207^{* *}$ & $.280^{* *}$ & .021 & .050 & .044 & -.098 & $-.118^{*}$ & $.218^{* *}$ & 1 & $.228^{* *}$ & .062 & .041 & .020 & -.008 & .02 & $.216^{* *}$ & .030 & $.263^{* *}$ & $.132^{* * 7}$ \\
\hline & .000 & .000 & .000 & .000 & .677 & .331 & .393 & .055 & .021 & .000 & & .000 & .222 & .421 & .693 & .869 & .638 & .000 & .556 & .000 & .009 \\
\hline GROUP & $.406^{* *}$ & $-.615^{* *}$ & $.498^{* \pi}$ & $.528^{* \pi}$ & -.028 & $.134^{* \pi}$ & .049 & .012 & .034 & $-.124^{*}$ & $.230^{* \pi *}$ & 1 & .015 & -.048 & -.034 & -.050 & .058 & $.456^{* *}$ & -.025 & $.227^{* *}$ & -.021 \\
\hline & .000 & .000 & .000 & .000 & .588 & .009 & .337 & .811 & .504 & .015 & .000 & & .772 & .346 & .503 & .332 & .261 & .000 & .631 & .000 & .681 \\
\hline$I N V$ & .079 & .014 & .041 & .008 & -.040 & $-.114^{*}$ & -.044 & -.015 & .001 & -.036 & .031 & -.016 & 1 & $.294^{* *}$ & -.014 & .0 & -.006 & .041 & -.070 & -.0 & -.010 \\
\hline & .123 & .783 & .421 & .876 & .432 & .026 * & .390 & .777 & .988 & .487 & .551 & .753 & & .000 & .781 & .066 & .903 & .424 & .174 & .385 & .845 \\
\hline$R E C$ & -.019 & -.012 & .050 & -.017 & -.064 & $-.121^{*}$ & .001 & -.017 & -.023 & -.055 & .040 & -.034 & $.640^{* *}$ & 1 & $.111^{*}$ & $-.111^{*}$ & .015 & -.056 & .011 & -.036 & .041 \\
\hline & .716 & .818 & .331 & .737 & .214 & .017 & .986 & .744 & .660 & .27 & .43 & .503 & .000 & & .029 & .030 & .7 & .277 & .837 & & .418 \\
\hline CASH & .002 & .009 & -.033 & .003 & -.014 & $-.249^{-\pi *}$ & -.069 & -.018 & -.041 & .03 & .01 & -.027 & -.076 & -.016 & 1 & -.065 & -.0 & .004 & 30 & .001 & .052 \\
\hline & .974 & .862 & .515 & .950 & .783 & .000 & .178 & .723 & .427 & .53 & .78 & .599 & .13 & .759 & & .200 & & & & & .306 \\
\hline$A G E$ & -.039 & .042 & -.025 & -.023 & -.040 & -.088 & .024 & .021 & -.049 & .012 & -.028 & -.061 & .027 & -.029 & -.003 & 1 & .020 & -.019 & -.091 & -.050 & .080 \\
\hline & .442 & .414 & .626 & .654 & .430 & .08 & .637 & .679 & .33 & .81 & .57 & .23 & .60 & .571 & & & .703 & .717 & .074 & & .118 \\
\hline IFRS & $.164^{* *}$ & -.089 & $.151^{* * \pi}$ & .093 & .078 & .029 & -.083 & .002 & -.019 & -.060 & .055 & .058 & .010 & .041 & -.023 & .023 & 1 & $.102^{*}$ & .032 & -.032 & .047 \\
\hline & .001 & $.083_{* \pi}$ & .003 & .069 & .129 & .571 & .104 & .969 & .717 & .241 & .284 & .261 & .84 & .419 & .651 & .660 & & .045 & .530 & .530 & .359 \\
\hline$N A T$ & $.359^{* *}$ & $-.319^{* *}$ & $.737^{* \pi}$ & $.348^{* \pi}$ & .035 & -.004 & -.052 & .036 & -.011 & -.092 & $.261^{* *}$ & $.456^{* *}$ & .05 & .054 & -.011 & -.023 & $.102^{*}$ & 1 & -.045 & $.239^{* *}$ & -.008 \\
\hline & .000 & .000 & .000 & .000 & .49 & .94 & .314 & .4 & .82 & .07 & .00 & .00 & .2 & .291 & .8 & .6 & .045 & & .382 & .000 & .870 \\
\hline$R O A$ & .045 & .039 & .021 & -.021 & $.101^{*}$ & $-.118^{*}$ & $-.211^{* *}$ & -.055 & .007 & $-.172^{* *}$ & .001 & .015 & .005 & .034 & .039 & $-.120^{*}$ & .025 & -.020 & 1 & -.039 & .038 \\
\hline & .374 & .450 & .682 & .678 & .048 & .020 & .000 & .283 & .892 & .001 & .985 & .776 & .921 & .510 & .447 & .018 & .629 & .693 & & .444 & .460 \\
\hline LEGFORM & $.236^{* *}$ & $-.255^{* *}$ & $.150^{* \pi}$ & $.263^{* \pi}$ & .055 & .059 & .043 & .070 & -.068 & -.064 & $.257^{* *}$ & $.227^{* *}$ & -.034 & -.014 & -.040 & -.034 & -.032 & $.239^{* *}$ & -.015 & 1 & .002 \\
\hline & .000 & .000 & .003 & .000 & .285 & .247 & .401 & .172 & .185 & .207 & .000 & .000 & .50 & .789 & .439 & .508 & .530 & .000 & .768 & & .976 \\
\hline$I N D$ & .005 & -.028 & -.036 & .006 & .041 & -.034 & -.036 & .014 & -.009 & $.205^{* *}$ & .100 & -.021 & .046 & .091 & .097 & $.119^{*}$ & .047 & -.008 & .071 & .002 & 1 \\
\hline & .927 & .578 & .486 & .909 & .422 & .507 & .484 & .785 & .855 & .000 & .051 & .681 & .366 & .075 & .058 & .020 & .359 & .870 & .168 & .976 & \\
\hline
\end{tabular}

This table reports Pearson (Spearman) correlation coefficients for the model variables above (below) the diagonal. ** Correlation is significant at the $1 \%$ level (2-tailed) and * at the $5 \%$ level (2-tailed). Probabilities are shown in italics. For variable definitions, see Table 3. 
Table 7. A logistic regression model of auditor choice in Italian non-listed firms

\begin{tabular}{|c|c|c|c|c|c|c|}
\hline Variables & Hyp. & $\begin{array}{l}\text { Exp. } \\
\text { sign }\end{array}$ & Coefficient & S.E. & $\mathrm{z}$ & p-value \\
\hline Constant & & & -7.30 & 1.689 & -4.322 & $<0.000 * * *$ \\
\hline \multicolumn{7}{|c|}{ a) Agency factors } \\
\hline$O W N$ & H1a & - & -0.320 & 0.508 & -0.6319 & 0.528 \\
\hline$F O W N$ & $\mathrm{H} 1 \mathrm{~b}$ & + & 0.475 & 0.478 & 0.994 & 0.320 \\
\hline$B O A R D$ & $\mathrm{H} 1 \mathrm{c}$ & $+/-$ & 1.012 & 0.461 & 2.192 & $0.028 * *$ \\
\hline FSALES & $\mathrm{H} 2$ & + & -0.151 & 0.749 & -0.201 & 0.840 \\
\hline$L E V$ & H3 & + & 0.980 & 0.825 & 1.188 & 0.235 \\
\hline$A P G R O W$ & H3 & + & -0.222 & 0.328 & -0.677 & 0.498 \\
\hline \multicolumn{7}{|c|}{ b) Organizational complexity and risk factors } \\
\hline$S I Z E$ & $\mathrm{H} 4 \mathrm{a}$ & + & 0.523 & 0.148 & 3.524 & $0.000 * * *$ \\
\hline SALARY & $\mathrm{H} 4 \mathrm{~b}$ & - & 1.854 & 1.165 & 1.591 & 0.111 \\
\hline COMPLEX & $\mathrm{H} 4 \mathrm{~b}$ & - & -2.046 & 0.724 & -2.826 & $0.005 * * *$ \\
\hline GROUP & $H 4 c$ & + & 0.821 & 0.388 & 2.118 & $0.034 * *$ \\
\hline$I N V$ & $H 4 d$ & - & 0.373 & 0.175 & 2.133 & $0.033 * *$ \\
\hline$R E C$ & $H 4 d$ & - & -0.369 & 0.219 & -1.684 & $0.092 *$ \\
\hline CASH & $H 4 d$ & - & 1.637 & 1.618 & 1.012 & 0.312 \\
\hline SALEGROW & $H 4 d$ & - & -0.485 & 0.741 & -0.655 & 0.512 \\
\hline$A G E$ & $H 4 e$ & - & -0.021 & 0.180 & -0.115 & 0.908 \\
\hline \multicolumn{7}{|c|}{ c) Control variables } \\
\hline$R O A$ & & - & 0.009 & 0.017 & 0.536 & 0.592 \\
\hline LEGFORM & & + & 0.543 & 0.321 & 1.693 & $0.090 *$ \\
\hline IFRS & & + & 2.447 & 1.235 & 1.981 & $0.048 * *$ \\
\hline$N A T$ & & + & 0.238 & 0.490 & 0.486 & 0.627 \\
\hline$I N D$ & & $\mathrm{n} / \mathrm{a}$ & 0.215 & 0.331 & 0.651 & 0.515 \\
\hline
\end{tabular}

Model diagnostics:

-2 Log likelihood: -149.237

Adj. R-Squared: $22.70 \%$; R-Square McFadden: $32.23 \%$

This table presents the results of a logistic regression model of the likelihood that non-listed firms engage an external auditor as opposed to a BSA. The model includes observations for the year 2009. For variable definitions please see Table $3 .^{*},{ }^{* *}$ and $* * *$ indicate statistical significance at the $10 \%, 5 \%$ and $1 \%$ levels, respectively. 